\title{
Improving Outdoor Thermal Comfort for Elderly in Residential Complexes
}

\author{
E. Samadpour Shahrak, H. Sattari Sarbangholi*, M. S. Moosavi
}

Department of Architecture and Urban Planning, Islamic Azad University, Tabriz Branch, Tabriz, Iran

\section{PAPER INFO}

Paper history:

Received 06 November 2021

Accepted in revised form 13 January 2022

\section{Keywords:}

Outdoor

Predicted mean vote

Thermal comfort

Universal thermal climate index

Elderly

\section{$A \begin{array}{llllllllllllllll}A & B & T & A & C & T\end{array}$}

One of the crucial factors for the presence of more people outdoors is to create comfortable conditions. This issue is significant for the elderly due to the different physical conditions. The purpose of this study is to improve the micro-climatic condition around residential complexes considering the elderly in a linear type. For this purpose, two physical indicators, the ratio of the height of buildings to their distance from each other (H/D) and the orientation of them towards the street, were investigated. Regarding H/D, ratios of $0.5,1,1.5$, and 2 , and about the orientation factor, angles of $135^{\circ}$ to $200^{\circ}$ were examined. This study was conducted outdoors around residential complexes in Iran, Tabriz, with a cold semi-arid climate. Envi-met software model 4.4.5 was used for the simulation. The days June 22 and December 22, 2020 were selected as one of the hottest and coldest day of the year. Two indexes of the Predicted Mean Vote (PMV) and the Universal Thermal Climate Index (UTCI) were examined as essential thermal comfort indexes. Also, for validation, local and field data in six days (21, 22, 23 June in summer and 21, 22, 23 December in winter) were extracted and compared with the data of the software. The results display, the ratio of $\mathrm{H} / \mathrm{D}=1.5$ and the angles of $135^{\circ}$ and $145^{\circ}$ were the most suitable comfort conditions.

\section{INTRODUCTION}

Global warming, increasing population, and urban density highlight the importance of paying attention to the impact of buildings design on outdoor thermal comfort. Since 2002, the world's primary energy demand increased $1.7 \%$ per year, and it is expected to expand more than $50 \%$ by 2030 [1]. One of the factors that cause climate change is an increasing trend in generation of greenhouse gases [2]. Therefore, the use of renewable energy and attention to environmental issues is important [3]. So, it is vital to identify the environmental characteristics outdoors and use its results to optimize urban construction. Regarding the effect of geometry of buildings on thermal comfort in the outdoor space, various factors such as $H / D$, and the orientation of them are involved. Different building forms can create different microclimatic conditions in the environment around them. Changing the microclimate conditions of the area will change the comfort conditions. Mirzabeigi et al. [4] evaluate building energy performance and outdoor thermal comfort of different typologies. Aperda et al. [5] have studied the impact of urban block morphology on microclimate conditions and thermal comfort in the EuroMediterranean region in seven different types of blocks. In this study, the results were compared between blocks through morphometric parameters. Andreou [6] has studied the parameters affecting the thermal comfort conditions in urban canyons in two different traditional and modern areas. Martinelli and Matzarakis [7] have studied the influence of the H/D ratio on thermal comfort in different regions of Italy. They have concluded that this factor has a significant effect on thermal comfort. They have recommended high H/D ratios of 4:5 to 5:5 for warm climates and low-medium H/D proportions of $3: 5$ to $4: 5$ for cold climates. Galal et al. [8] have studied different urban forms and H/D ratios of buildings and their impact on thermal comfort conditions in the new city of Aswan. Also, various researches in the field of outdoor thermal comfort have been done by considering different age

\footnotetext{
*Corresponding Author Email: $\quad$ sattari@iaut.ac.ir (H. Sattari Sarbangholi)
} 
groups. Yao et al. [9] have studied outdoor thermal comfort by considering older people in summer and winter. They have concluded that the elderly are more sensitive to climatic changes in winter than in summer. Jiao et al. [10] concluded that there was a greater difference between the PMV index and the actual neutral temperature in winter than in summer. Forcada et al. [11] concluded that older people prefer higher temperatures than others by using the PMV index.

Several researches have been conducted regarding the effect of the shape, H/D ratio, and orientation of buildings on thermal comfort in the outdoors, and some of them have been considered different age groups, such as the elderly. However, most of these studies have been conducted in the hot dry or humid climate areas. In most studies, the summer season has been analyzed and studied. Also, most studies have examined the general orientation in the N-S, E-W, NE-SW, NW-SE directions. This article examines the relationship between the H/D ratio and the orientation of buildings at more precise angles. Also, because aging is an inevitable biological process that affects most people and in Iran, the population of this age group is increasing, so the mentioned factors were examined by considering this age group. On the other hand, open space between residential complexes can accept various activities such as walking, sitting, social discussions, etc. So creating thermal comfort in this region is essential. Therefore, this research has been done around one of the residential buildings in Tabriz city (Iran) with cold semi-arid in one of the coldest and hottest days of the year.

\section{RESEARCH METHOD AND STUDY AREA}

\section{Study area}

Tabriz $\left(38.8^{\circ} \mathrm{N}, 46.30^{\circ} \mathrm{E}\right)$ is a city in the northwestern of Iran, the capital of East Azerbaijan Province. According to statistical data, in 2016, it had a population of about
$1,700,000$, and its climate is cold semi-arid. Its elevation range is between 1350 and 1600 meters above sea level. The annual precipitation is around 320 millimeters. Golpark complex, located in the east of Tabriz with a linear type, is the selected area for this research (Figure 1). The blocks of the residential complex have four stories located at a distance of about 20 meters from each other. The material of the ground is mostly asphalt and soil, and the material of the facade is white and colored cement. The blocks have a NW-SE extension.

\section{Simulation method}

\section{The main variables of thermal comfort}

Thermal comfort is the mental condition that expresses satisfaction. The word mental conditions refers to the fusion of mental and physical conditions called thermal comfort. There are various indexes such as PMV, PET, UTCI, TSV, ASV, etc. to evaluate comfort conditions. Among these indexes, the Predicted Mean Vote (PMV) was found in literature [12]. They confirmed this index for the elderly by using multiple experiments between the elderly and other age groups [12]. This index considers air temperature, mean radiant temperature, relative humidity, and two personal variables, including clothing resistance and activity level, as a composite index. This index determines the coefficients that are measured according to Ashrae's heat scale and indicates the average heat sensation of a large group of people in the designated space [12]. It is obtained through the following equation:

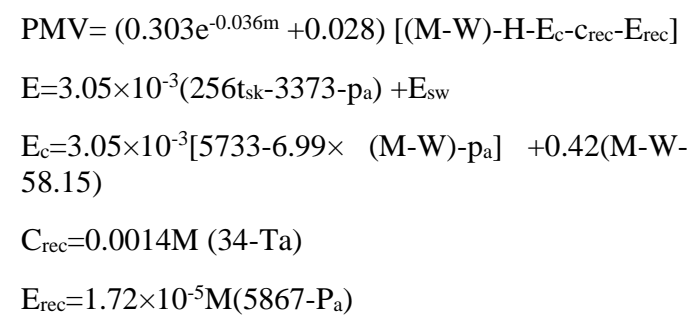

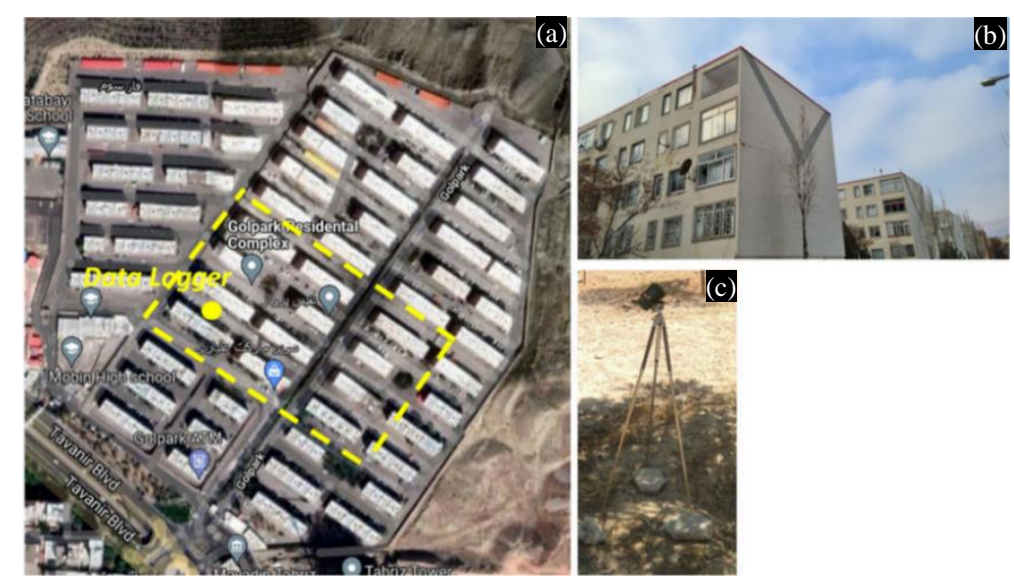

Figure 1. Pictures of the study area, (a) Aerial map of site plan and the locating of the data logger in the area, (b) Image of the blocks, (c) Location of data logger 
The value of $\mathrm{H}$ can be measured directly and can also be calculated through the following equation:

$$
\mathrm{H}=\mathrm{K}_{\mathrm{cl}}=\mathrm{t}_{\mathrm{sk}}-\mathrm{t}_{\mathrm{cl}} / \mathrm{I}_{\mathrm{cl}}
$$

where $\mathrm{C}_{\mathrm{rec}}$ is convective heat transfer coefficient $\left(\mathrm{W} / \mathrm{m}^{2}\right)$, $\mathrm{E}_{\mathrm{rec}}$ is evaporation heat transfer coefficient $\left(\mathrm{W} / \mathrm{m}^{2}\right), \mathrm{E}_{\mathrm{sw}}$ is evaporation heat losses $\left(\mathrm{W} / \mathrm{m}^{2}\right), \mathrm{Icl}$ is average of clothing radiation $\left(\mathrm{W} / \mathrm{m}^{2}\right)$, Ec is Evaporative heat exchange on the surface of the skin $\left(\mathrm{W} / \mathrm{m}^{2}\right), \mathrm{M}$ stands for Metabolic rate $\left(\mathrm{W} / \mathrm{m}^{2}\right), \mathrm{Tcl}$ is Clothing surface temperature $\left({ }^{\circ} \mathrm{C}\right)$, Tsk is skin temperature, $\mathrm{W}$ is effective mechanical force $\left(\mathrm{W} / \mathrm{m}^{2}\right), \mathrm{H}$ is dry heat losses in convection, conduction and radiation $\left(\mathrm{W} / \mathrm{m}^{2}\right)$, Ta stands for air temperature, and $\mathrm{Pa}$ is the partial water vapour pressure in the air $\left(\mathrm{P}_{\mathrm{a}}\right)$.

Another index is the universal thermal climate index (UTCI), which is a human biometeorology parameter that is used to assess the correlation between the outdoor environment and human comfort. It is a measure of the human physiological response to the thermal environment. The value of this index depends on air temperature, wind speed, relative humidity, and mean radiant temperature. It is obtained through the following equation.

$$
\begin{aligned}
& \mathrm{UTCI}=\mathrm{f}\left(\mathrm{T}_{\mathrm{a}} ; \mathrm{T}_{\mathrm{mrt}} ; \mathrm{Va} ; \mathrm{Vp}\right)=\mathrm{Ta}+\operatorname{offset}(\mathrm{Ta} ; \mathrm{Tmrt} \text {; } \\
& \text { va; vp })
\end{aligned}
$$

where $T_{a}$ is air temperature, $T_{m r t}$ is mean radiant temperature, $\mathrm{Va}$ is wind speed, and $\mathrm{Vp}$ is Water vapor pressure.

These two indicators have been widely used by various researchers to measure outdoor thermal comfort [9, 13-15]. Also, by considering these two indicators, all climatic factors such as wind speed, relative humidity, air temperature, mean radiant temperature, etc., and individual characteristics such as age, type of clothing, etc., are taken into account. So, in this research, these two indices were examined.

\section{Simulation method}

According to the purpose of this research, the selected software should use the exact geographical and climatic location data of the study area, data analysis, buildings, and other surrounding factors. ENVI-met software is a holistic, three-dimensional microclimate model. It simulates the climatological interactions between surfaces, plants, and the atmosphere. Also, it analyses the effects of planning measures on the urban climate. It has validity and reliability due to the high correlation between the values obtained from field measurements and the simulation results in the software environment [16-18].

Due to the reasons, ENVI-met software (4.4.5) was used to simulate the surrounding environmental conditions. The information entered in the software can be seen in Table 1.

The simulation process is summarized as follow:

- Determining climatic conditions and extracting meteorological data
Table 1. Information entered software

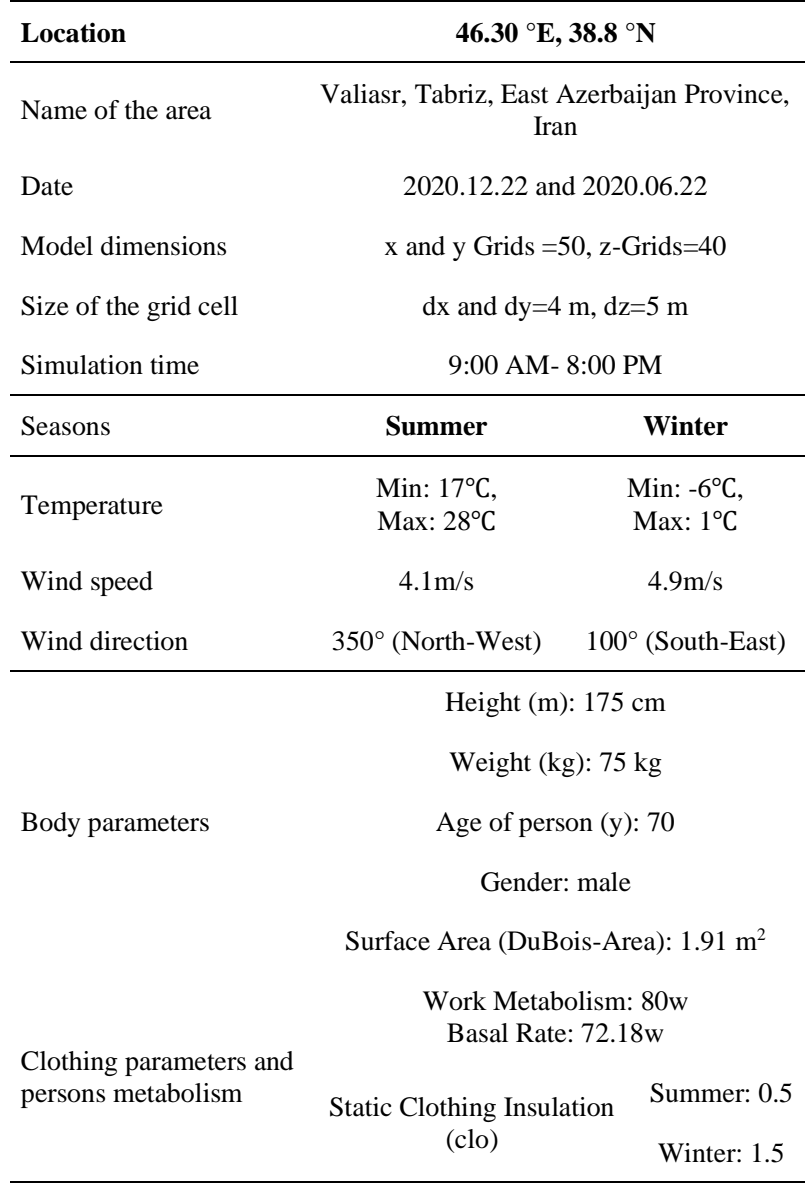

- Determining the time for analysis during summer and winter (June 22 and December 22, 2020) (The hottest and coldest days of the year) from 9 am to $8 \mathrm{pm}$, for 11 hours (The hours when most people are outdoors)

- Determining age, activity, and clothing parameters of the statistical society of the research (Age 70 was selected as the average age of the elderly in Iran)

- Modeling, software validation

- Modeling and reviewing outdoors thermal comfort considering different $\mathrm{H} / \mathrm{D}$ ratios and orientations

\section{Software validation}

In this paper, based on literature review $[14,16]$, relative humidity and air temperature $\left(\mathrm{RH}\right.$ and $\left.\mathrm{T}_{\mathrm{a}}\right)$ were measured and simulated for validation. Field data were collected and studied on 21, 22 and 23 June in summer, and 21, 22 and 23 December in winter, from 9 am to $8 \mathrm{pm}$, for 11 hours at $1.5 \mathrm{~m}$ above the ground (Figure 1). It was placed where it is not exposed by heavy shadows from buildings. Data logger specifications are EXTECH model RHT20 with accurate measurement (14-104 degrees Fahrenheit), $\pm 1.8^{\circ} \mathrm{F}$ and $(60-80 \%), \pm 3.5 \%$. In this model, $\mathrm{T}_{\mathrm{a}}$ and $\mathrm{RH}$ information are saved in the device's memory every 10 seconds. After extracting the data from the data logger, 
their average for each hour was calculated. The local information of the specified day was extracted from the meteorological site ${ }^{1}$. Then, these data were transferred to ENVI-met software. Finally, the data extracted from the data logger were compared with the output obtained from the software.

For data validation, as in previous research, two indicators, $\mathrm{R}^{2}$ and RMSE, were used. For the $\mathrm{T}_{\mathrm{a}}$ factor, $\mathrm{R}^{2}$ is equal to 0.89 in both seasons, and RMSE is equal to $0.59,0.48$ in summer and winter, respectively (Figures 2 and 3). For the RH factor, $\mathrm{R}^{2}$ is equal to $0.91, .094$ and RMSE is equal to $1.66,1.37$ in summer and winter, respectively (Figures 4 and 5). Previous research displays that $\mathrm{R}^{2}$ values from 0.52 to 0.96 and RMSE values from 0.26 to 4.83 are acceptable [14]. Therefore, the ENVI-met model is valid in this study.

\section{RESULTS}

To compare each index, four receptors in different parts of the site were selected in the Envi-met software (Figure 6 ). These receptors were located so they were scattered

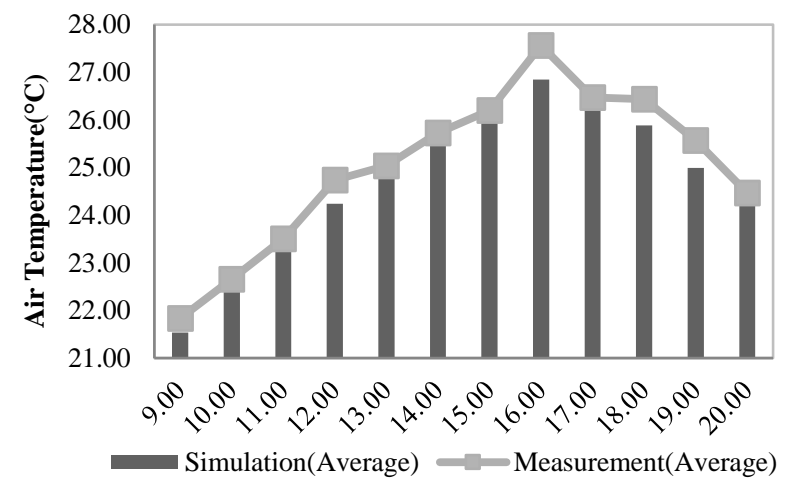

(a) on the site and could express the general condition of the site. Therefore, one receptor was placed in the center of the site (R3), another between two buildings (R1), and two other receptors were placed between four buildings $(\mathrm{R} 2, \mathrm{R} 4)$. The mentioned indices for each of the receptors were extracted from 9 am to $8 \mathrm{pm}$, Finally, four tables were used to analyze each factor. Also, because the average human height between sitting and standing position is about 1.50 meters, the simulation was measured at this height.

The first table in each of the indices displays the average of the factor in the four selected receptors at different times of the day ( 9 am to $8 \mathrm{pm}$ ) in different $\mathrm{H} / \mathrm{D}$ ratios. The second one shows the average of the same index in each receptor from 9 am to $8 \mathrm{pm}$. By analyzing these two tables and obtaining the best $\mathrm{H} / \mathrm{D}$ ratio in summer and winter, that ratio is selected. Also, to get the best building orientation, the average of factors is examined as in the previous tables in the third and fourth tables. For a more accurate data analysis, the figures extracted from Envi-met were examined in the hour when the average of the index is the highest.

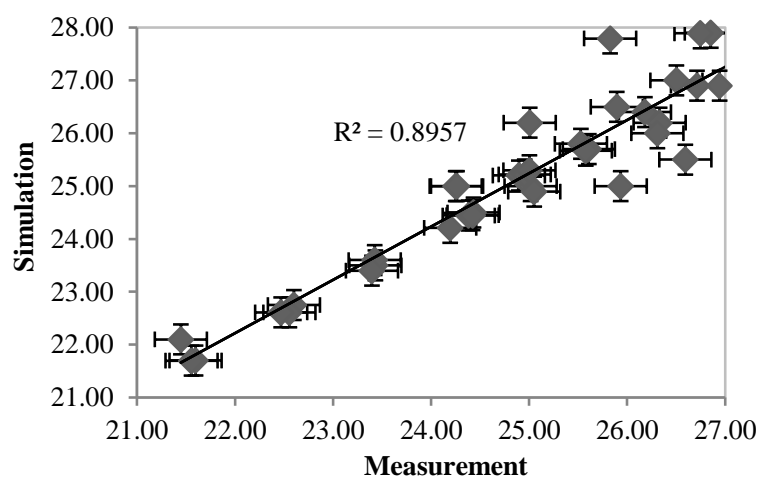

(b)

Figure 2. (a) The mean of air temperature in simulation and measurement, (b) the comparison of air temperature in the scattered graph in summer

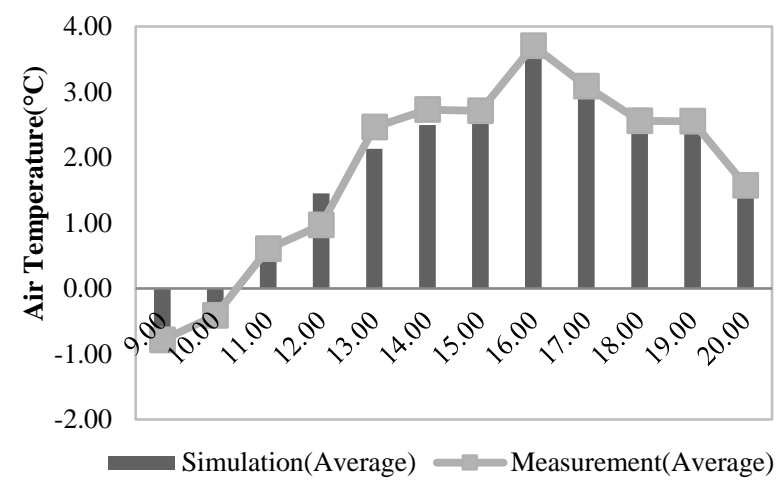

(a)

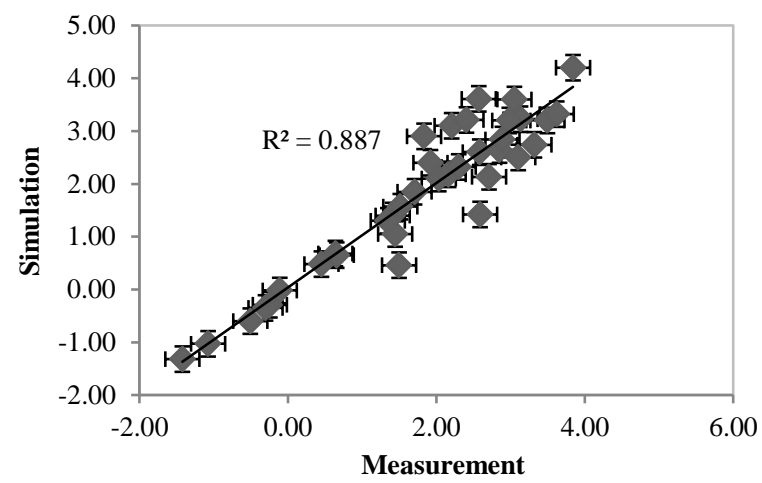

(b)

Figure 3. (a) The mean of air temperature in simulation and measurement, (b) the comparison of air temperature in the scattered graph in winter

\footnotetext{
${ }^{1}$ https://irimo.ir/far/index.php
} 


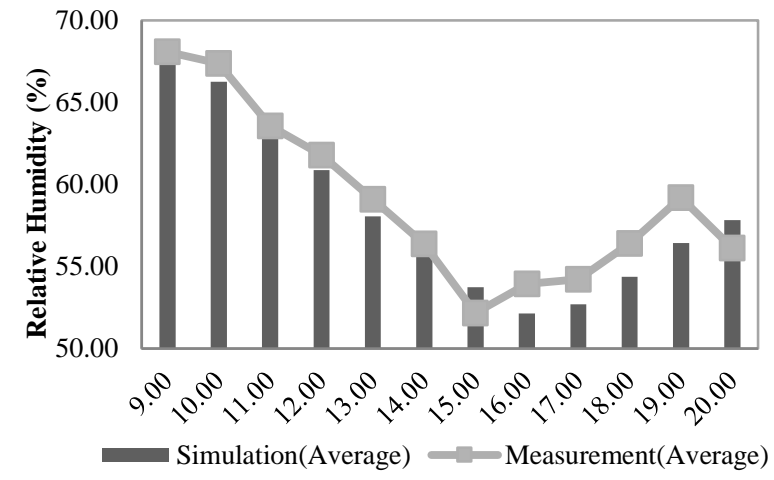

(a)

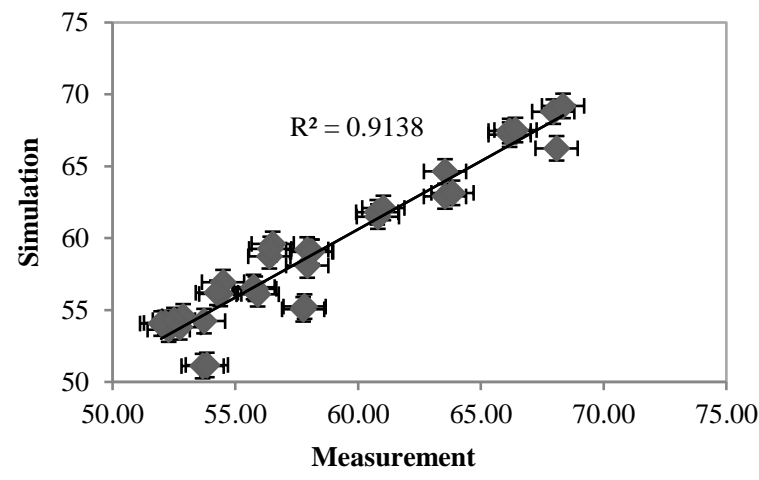

(b)

Figure 4. (a) The mean of relative humidity in simulation and measurement, (b) the comparison of relative humidity in the scattered graph in summer

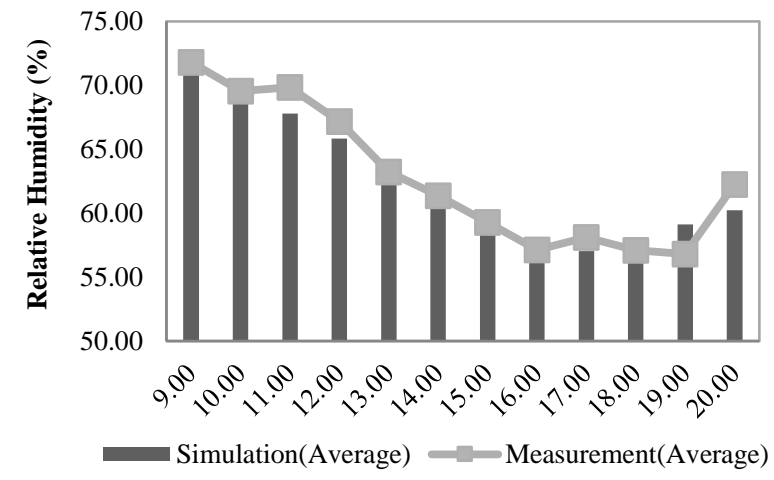

(a)

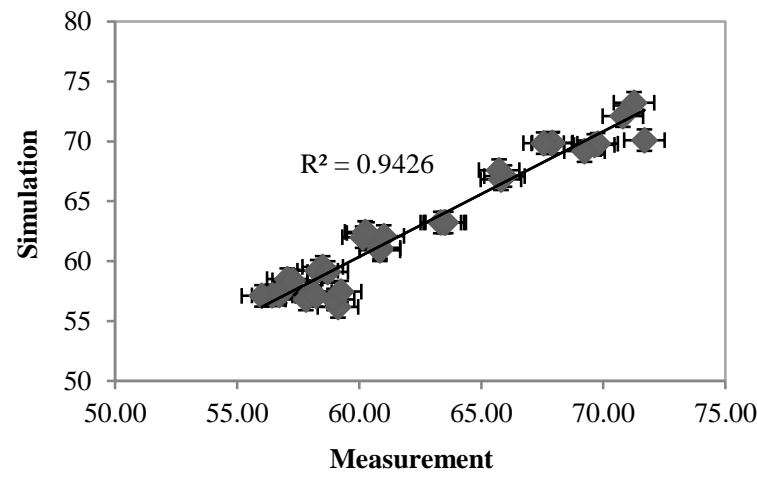

(b)

Figure 5. (a) The mean of relative humidity in simulation and measurement, (b) the comparison of relative humidity in the scattered graph in winter

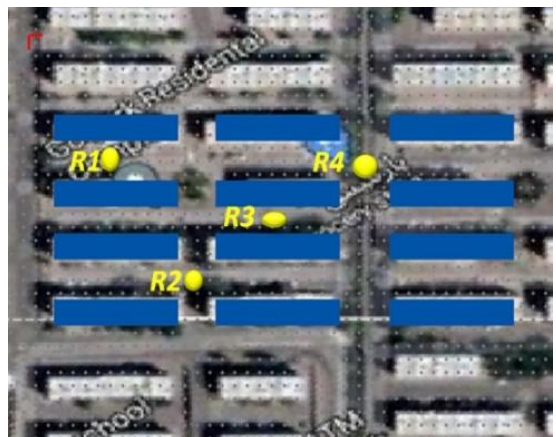

Figure 6. Location of selected receptors on the site

Considering the direction of shadow movement of buildings is an important factor in designing [19]. The proportion of H/D between blocks should not be such that the blocks overshadow each other because this factor causes higher energy consumption indoors. So, the options of H/D proportion $0.5,1,1.5,2$ were investigated. According to the distance of 20 meters between the blocks in the selected site, the height of the blocks was 10, 20, 30 , and 40, which indicate three to thirteen floor buildings. According to the orientation of blocks in residential complexes in the mentioned city, 8 angles with a difference of $10^{\circ}$ were selected because less than $10^{\circ}$, the extracted data are closer to each other, and more than that can reduce the verification of the result. The orientations of $200^{\circ}(\mathrm{O} 1), 195^{\circ}(\mathrm{O} 2), 185^{\circ}(\mathrm{O} 3), 175^{\circ}$ $(\mathrm{O} 4), 165^{\circ}(\mathrm{O} 5), 155^{\circ}(\mathrm{O} 6), 145^{\circ}(\mathrm{O} 7)$ and $135^{\circ}(\mathrm{O} 8)$ clockwise from north were selected and examined (Figure 7).

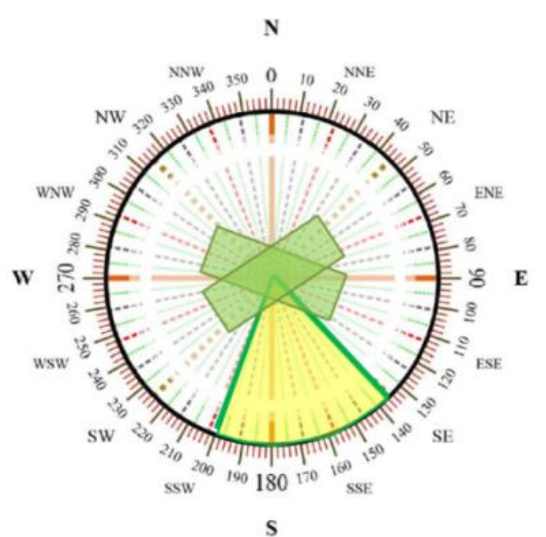

Figure 7. Different orientations of buildings 


\section{Predicted mean vote (PMV)}

\section{Comparison between H/D ratio and PMV}

Tables 2 and 3 display that in summer, with increasing $\mathrm{H} / \mathrm{D}$, the PMV declines. This reduction process has done in all studied hours. However, in some hours of the day, such as 2:00 pm and 3:00 pm, also from 5:00 pm, the value of the proportions of 1.5 and 2 are the same. The difference of PMV between the proportions of 0.5 and 2 is the highest from 9 am to $6 \mathrm{pm}$. At $12 \mathrm{pm}, 5 \mathrm{pm}$, and 6 $\mathrm{pm}$, the mean difference reaches about $0.55,0.91,0.34$, respectively. This difference in numbers was the lowest at 7 and 8 pm, getting 0.01 at these hours (Table 2). When the proportions increase from 0.5 to 1 , the mean of PMV declines about 0.05 , when proportion rises from 1 to 1.5 , the mean of PMV declines about $0.24^{\circ} \mathrm{C}$, and it makes no difference when it rises from 1.5 to 2 (Table 3).

In winter, the $\mathrm{H} / \mathrm{D}=2$ has the lowest, and the $\mathrm{H} / \mathrm{D}=0.5$ has the highest mean of PMV in all studied hours and receptors (Tables 2 and 3). Also, at 5 pm, 7 pm, and 8 pm, the values of the proportions of 0.5 and 1 are the same. The difference of mean PMV between the proportions $\mathrm{H} / \mathrm{D}=0.5$ and $\mathrm{H} / \mathrm{D}=2$ from 9 am to $3 \mathrm{pm}$ is the highest, and at $10 \mathrm{am}, 1 \mathrm{pm}$, and $2 \mathrm{pm}$, the mean difference reaches about $0.69,0.30,0.29$, respectively (Table 2 ). When these proportions change from 0.5 to 1 , the mean of PMV declines about 0.1 . The mean of PMV declines about 0.05 , when this proportion rises from 1 to 1.5 , Changing this proportion from 1.5 to 2 , it declines about 0.04 (Table 3).

Therefore, it can be concluded that with rising H/D proportion in summer and winter, the mean of PMV declines. In summer, the reduction process is the highest when it changes from a proportion of 1 to 1.5 , and when it shifts from 1.5 to 2 , it makes no difference. In winter, the reduction process is the highest when it changes from 0.5 to 1 , and it is almost the same when it changes from a proportion of 1 to 1.5 and 1.5 to 2 . The reduction process of PMV in summer is more than winter. This indicates that increasing the H/D proportion has a more important impact on declining this index in summer.

Table 2. Mean of PMV in four receptors from 9:00 am to 8:00 pm

\begin{tabular}{|c|c|c|c|c|c|c|c|c|c|c|c|c|c|}
\hline & \multirow[b]{2}{*}{ H/D } & \multicolumn{12}{|c|}{ Time } \\
\hline & & 09.00 & 10.00 & 11.00 & 12.00 & 13.00 & 14.00 & 15.00 & 16.00 & 17.00 & 18.00 & 19.00 & 20.00 \\
\hline \multirow{6}{*}{ Summer } & 0.5 & 1.57 & 1.79 & 1.86 & 2.06 & 2.49 & 2.95 & 3.22 & 3.29 & 2.88 & 1.39 & 0.23 & 0.05 \\
\hline & 1 & 1.55 & 1.70 & 1.85 & 2.05 & 2.49 & 2.92 & 3.17 & 3.24 & 2.83 & 1.11 & 0.23 & 0.05 \\
\hline & 1.5 & 1.37 & 1.51 & 1.66 & 1.52 & 2.27 & 2.69 & 3.00 & 3.08 & 1.97 & 1.05 & 0.22 & 0.04 \\
\hline & 2 & 1.36 & 1.50 & 1.65 & 1.51 & 2.26 & 2.69 & 3.00 & 3.07 & 1.97 & 1.05 & 0.22 & 0.04 \\
\hline & Min & 1.36 & 1.50 & 1.65 & 1.51 & 2.26 & 2.69 & 3.00 & 3.07 & 1.97 & 1.05 & 0.22 & 0.04 \\
\hline & $\begin{array}{c}\text { Max- } \\
\text { Min }\end{array}$ & 0.21 & 0.29 & 0.21 & 0.55 & 0.23 & 0.26 & 0.22 & 0.22 & 0.91 & 0.34 & 0.01 & 0.01 \\
\hline \multirow{6}{*}{ Winter } & 0.5 & -5.83 & -5.06 & -4.75 & -4.49 & -4.34 & -4.85 & -4.92 & -5.05 & -5.27 & -5.40 & -5.53 & -5.68 \\
\hline & 1 & -5.86 & -5.61 & -4.86 & -4.67 & -4.52 & -4.98 & -4.99 & -5.04 & -5.27 & -5.39 & -5.53 & -5.68 \\
\hline & 1.5 & -5.90 & -5.69 & -4.92 & -4.73 & -4.59 & -5.08 & -5.05 & -5.08 & -5.30 & -5.43 & -5.56 & -5.71 \\
\hline & 2 & -5.94 & -5.75 & -4.97 & -4.77 & -4.64 & -5.14 & -5.10 & -5.12 & -5.34 & -5.46 & -5.60 & -5.74 \\
\hline & $\operatorname{Max}$ & -5.83 & -5.06 & -4.75 & -4.49 & -4.34 & -4.85 & -4.92 & -5.04 & -5.27 & -5.39 & -5.53 & -5.68 \\
\hline & $\begin{array}{l}\text { Max- } \\
\text { Min }\end{array}$ & 0.11 & 0.69 & 0.22 & 0.28 & 0.30 & 0.29 & 0.18 & 0.08 & 0.07 & 0.07 & 0.07 & 0.07 \\
\hline
\end{tabular}

Table 3. Mean of PMV in each of the receptors from 9:00 am to 8:00 pm

\begin{tabular}{|c|c|c|c|c|c|c|c|c|c|c|}
\hline \multirow{2}{*}{$\begin{array}{l}\text { PMV } \\
\text { H/D }\end{array}$} & \multicolumn{5}{|c|}{ Summer } & \multicolumn{5}{|c|}{ Winter } \\
\hline & 0.5 & 1 & 1.5 & 2 & Min & 0.5 & 1 & 1.5 & 2 & Max \\
\hline R1 & 2.06 & 2.05 & 1.90 & 1.90 & 1.90 & -5.26 & -5.32 & -5.37 & -5.41 & -5.26 \\
\hline $\mathbf{R 2}$ & 1.90 & 1.86 & 1.63 & 1.63 & 1.63 & -4.96 & -5.05 & -5.08 & -5.11 & -4.96 \\
\hline $\mathbf{R 3}$ & 2.05 & 1.96 & 1.71 & 1.71 & 1.71 & -5.23 & -5.33 & -5.40 & -5.47 & -5.23 \\
\hline R4 & 1.91 & 1.86 & 1.55 & 1.54 & 1.54 & -4.95 & -5.10 & -5.16 & -5.20 & -4.95 \\
\hline
\end{tabular}


Figures 8 and 9 display the PMV index, extracted from the software at $4 \mathrm{pm}$ in summer and $1 \mathrm{pm}$ in winter (the hour when the PMV is the highest). In these figures, the effect of increasing the height on this index can be seen in both seasons, and confirm what has been said. As a result, the ratio of $H / D=0.5$ is the best option for winter, and $H / D=2,1.5$ is the best option for summer.

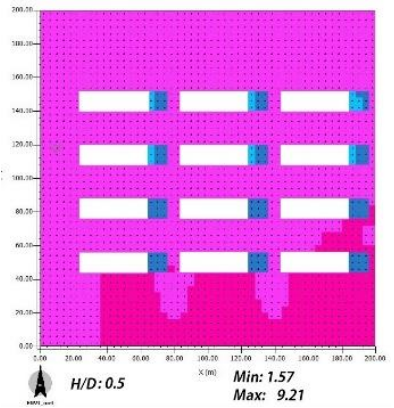

(a)

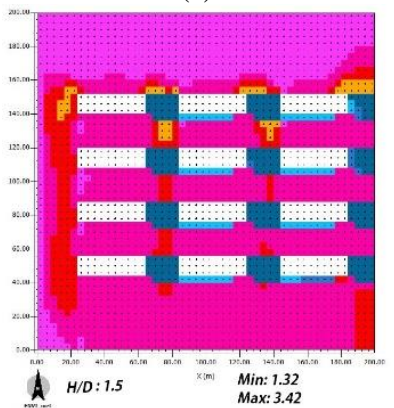

(c)

\section{The effect of buildings orientation on PMV}

Table 4 shows that in summer during most hours of the day, the average of PMV is the lowest at the angles of $135^{\circ}$ and $145^{\circ}$, and the highest at the angles of $175^{\circ}$, $185^{\circ}, 195^{\circ}$, and $200^{\circ}$. The average of this index in receptors 1 and 3 is the lowest at an angle of $135^{\circ}$ and is equal to 1.08 and 1.10, respectively. In receptors 2 and 4,

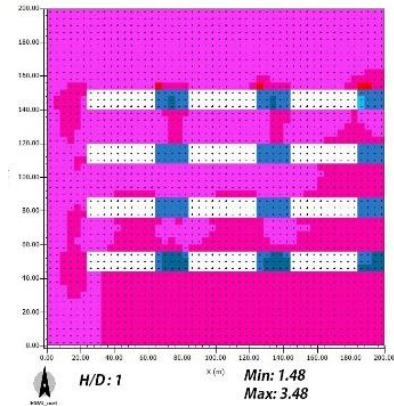

(b)

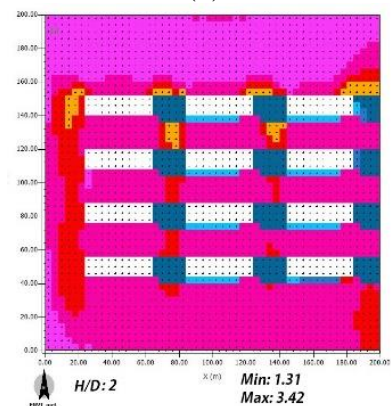

(d)

Figure 8. Display of PMV at $4 \mathrm{pm}$ in different H/D proportions in summer, (a) $\mathrm{H} / \mathrm{D}=0.5$, (b) $\mathrm{H} / \mathrm{D}=1$, (c) $\mathrm{H} / \mathrm{D}=1.5$, (d) $\mathrm{H} / \mathrm{D}=2$

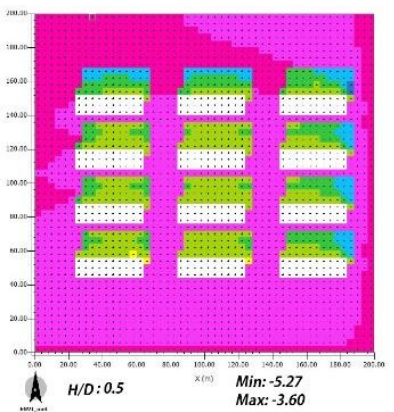

(a)

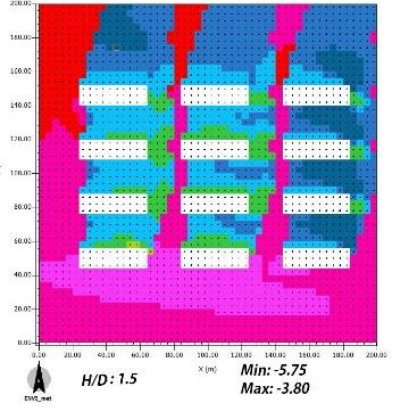

(c)

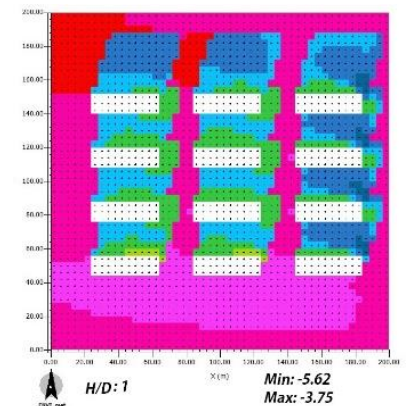

(b)

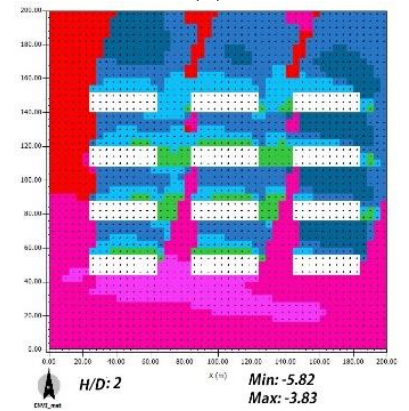

(d)

Figure 9. Display of PMV at $1 \mathrm{pm}$ in different H/D proportions in winter, (a) H/D=0.5, (b) H/D=1, (c) H/D=1.5, (d) H/D=2 
Table 4. Mean of PMV in four receptors from 9 am to $8 \mathrm{pm}$ at different orientations

\begin{tabular}{|c|c|c|c|c|c|c|c|c|c|c|c|c|c|}
\hline & \multirow[b]{2}{*}{ Orientation } & \multicolumn{12}{|c|}{ Time } \\
\hline & & 09.00 & 10.00 & 11.00 & 12.00 & 13.00 & 14.00 & 15.00 & 16.00 & 17.00 & 18.00 & 19.00 & 20.00 \\
\hline \multirow{10}{*}{ Summer } & 01 & 1.45 & 1.61 & 1.75 & 1.94 & 2.10 & 2.62 & 1.63 & 1.98 & 2.03 & 1.77 & 0.18 & -0.01 \\
\hline & 02 & 1.45 & 1.59 & 1.68 & 1.92 & 2.10 & 2.61 & 2.31 & 1.99 & 2.77 & 1.77 & 0.18 & 0.01 \\
\hline & $\mathbf{O 3}$ & 1.39 & 1.55 & 1.66 & 1.84 & 2.22 & 2.72 & 3.01 & 3.09 & 2.68 & 1.03 & 0.20 & 0.02 \\
\hline & 04 & 1.37 & 1.54 & 1.26 & 1.80 & 2.25 & 2.65 & 2.94 & 3.02 & 1.57 & 1.07 & 0.25 & 0.07 \\
\hline & 05 & 0.65 & 0.48 & 1.27 & 1.78 & 2.19 & 2.64 & 2.88 & 1.90 & 1.25 & 0.81 & 0.24 & 0.06 \\
\hline & 06 & 0.05 & 0.47 & 1.30 & 1.82 & 2.20 & 2.61 & 1.60 & 1.54 & 1.18 & 0.75 & 0.20 & 0.02 \\
\hline & 07 & -0.02 & 0.37 & 1.25 & 1.53 & 2.00 & 2.60 & 1.52 & 1.44 & 1.13 & 0.70 & 0.17 & 0.00 \\
\hline & 08 & -0.07 & 0.93 & 1.22 & 1.53 & 1.88 & 1.54 & 1.45 & 1.36 & 1.06 & 0.66 & 0.16 & -0.01 \\
\hline & MIN & -0.07 & 0.37 & 1.22 & 1.53 & 1.88 & 1.54 & 1.45 & 1.36 & 1.06 & 0.66 & 0.16 & -0.01 \\
\hline & Max-Min & 1.52 & 1.24 & 0.53 & 0.41 & 0.38 & 1.18 & 1.56 & 1.73 & 1.71 & 1.11 & 0.09 & 0.08 \\
\hline \multirow{10}{*}{ Winter } & 01 & -5.40 & -5.56 & -4.75 & -4.50 & -4.40 & -4.35 & -4.44 & -5.07 & -5.30 & -5.42 & -5.56 & -5.70 \\
\hline & 02 & -5.87 & -5.55 & -4.75 & -4.51 & -4.41 & -4.35 & -4.96 & -5.07 & -5.30 & -5.42 & -5.56 & -5.71 \\
\hline & $\mathbf{O 3}$ & -5.86 & -5.55 & -4.73 & -4.50 & -4.40 & -4.35 & -4.95 & -5.07 & -5.29 & -5.42 & -5.55 & -5.70 \\
\hline & 04 & -5.80 & -5.05 & -4.74 & -4.48 & -4.34 & -4.84 & -4.90 & -5.04 & -5.26 & -5.38 & -5.52 & -5.66 \\
\hline & 05 & -5.76 & -5.03 & -4.74 & -4.48 & -4.34 & -4.75 & -4.82 & -4.84 & -5.20 & -5.32 & -5.45 & -5.59 \\
\hline & 06 & -5.34 & -5.03 & -4.73 & -4.48 & -4.82 & -4.73 & -4.36 & -4.67 & -5.12 & -5.24 & -5.38 & -5.52 \\
\hline & O7 & -5.34 & -5.01 & -4.69 & -4.46 & -4.80 & -3.81 & -3.94 & -4.43 & -5.07 & -5.19 & -5.32 & -5.45 \\
\hline & 08 & -5.35 & -5.00 & -4.67 & -4.93 & -3.85 & -3.81 & -3.93 & -4.66 & -5.10 & -5.22 & -5.35 & -5.48 \\
\hline & Max & -5.34 & -5.00 & -4.67 & -4.46 & -3.85 & -3.81 & -3.93 & -4.43 & -5.07 & -5.19 & -5.32 & -5.45 \\
\hline & Max-Min & 0.54 & 0.56 & 0.08 & 0.46 & 0.97 & 1.03 & 1.04 & 0.64 & 0.23 & 0.24 & 0.25 & 0.25 \\
\hline
\end{tabular}

it has the lowest value at an angle of $155^{\circ}$ and is equal to 1.03 and 1.00 , respectively. Also, the angle of $145^{\circ}$ has a low value. As in receptor 2 is equal to 1.05 , which is very little different from the value at an angle of $155^{\circ}$, and in receptor 4, the numerical value of the index is equal to its value at an angle of $155^{\circ}$. The highest value of PMV index is at the angles of $175^{\circ}$ and $185^{\circ}$ (Table 5). Also, the figures obtained from the software at $4 \mathrm{pm}$, the time when the PMV index reached its highest value, show that more favorable environmental conditions have been created at the angles of $135^{\circ}$ and $145^{\circ}$, and the PMV index is the highest at the angles of $175^{\circ}$ and $185^{\circ}$ (Figure 10).

In winter, during most hours of the day and also at most receptors, the average of the PMV is highest at the angle of $135^{\circ}$ and $145^{\circ}$ and lowest at the angles of $185^{\circ}$, $195^{\circ}$ and $200^{\circ}$ (Tables 4 and 5). The highest difference between the maximum and the minimum of this index is from $1 \mathrm{pm}$ to $3 \mathrm{pm}$, and in these hours, the average of this index is the highest at an angle of $135^{\circ}$ (Table 4). Also, the figures obtained from the software at $2 \mathrm{pm}$, the time when the PMV index reached its highest value, show that more favorable environmental conditions have been created at the angles of $135^{\circ}$ and $145^{\circ}$, and the PMV index is lowest at the angles of $195^{\circ}$ (Figure 11).

\section{Universal thermal climate index}

\section{Comparison between H/D ratio and UTCI}

In summer, the index of UTCI has a declining process with an increase in H/D ratio in all study hours and receptors, such as the PMV index (Tables 6 and 7). When these ratios increase from $\mathrm{H} / \mathrm{D}=0.5$ to $\mathrm{H} / \mathrm{D}=1$, the average of UTCI declines about $1.28^{\circ} \mathrm{C}$, and when this ratio rises from 1 to 1.5 , the average drops by about $2.33^{\circ} \mathrm{C}$ and changing this proportion from 1.5 to 2 , it decreases by about $0.02{ }^{\circ} \mathrm{C}$. The difference between the maximum and minimum average of the UTCI is the highest at $11 \mathrm{am}$ to $6 \mathrm{pm}$. It is equal to $7.24^{\circ} \mathrm{C}$ and $7.74^{\circ} \mathrm{C}$ at $12 \mathrm{pm}$ and $5 \mathrm{pm}$, respectively (Table 6).

In winter, like summer, the ratio of $\mathrm{H} / \mathrm{D}=0.5$ has the highest, and $\mathrm{H} / \mathrm{D}=2$ has the lowest average of UTCI in all study hours and receptors (Tables 6 and 7). The difference between the maximum and the minimum average of UTCI from 10 am to $2 \mathrm{pm}$ is the highest, and it is about $9.42^{\circ} \mathrm{C}$ at 10 am (Table 6). When the ratio changes from 0.5 to 1 , the average of this index decreases by about $1.3^{\circ} \mathrm{C}$, and when it changes from 1 to 1.5 , the average drops by about $0.88^{\circ} \mathrm{C}$. Also, in changing it from 1.5 to 2 , the average of UTCI declines about $0.84^{\circ} \mathrm{C}$ (Tables 6 and 7). 


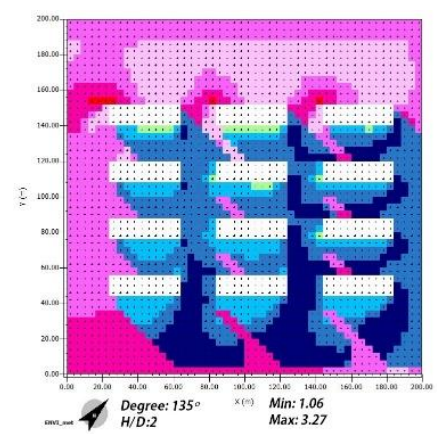

(a)

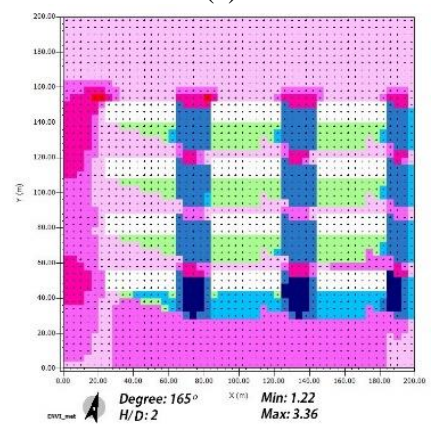

(d)

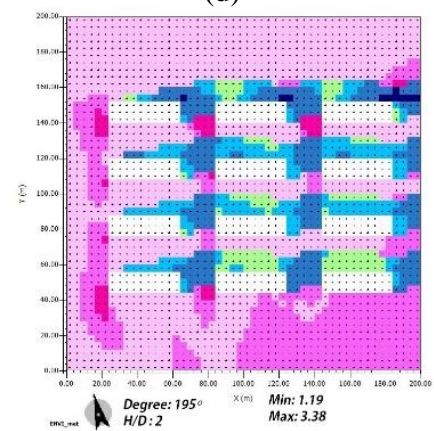

(g)

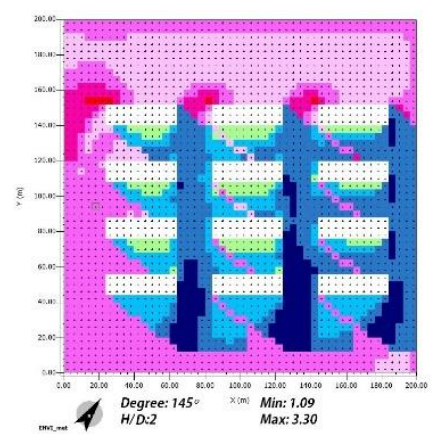

(b)

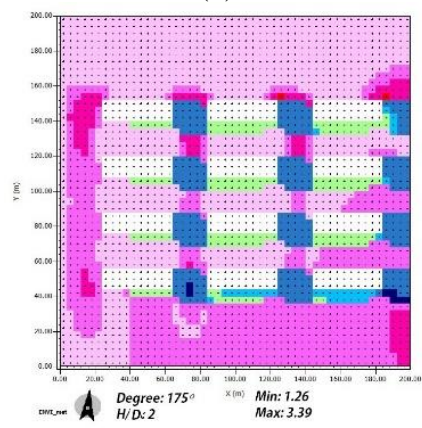

(e)

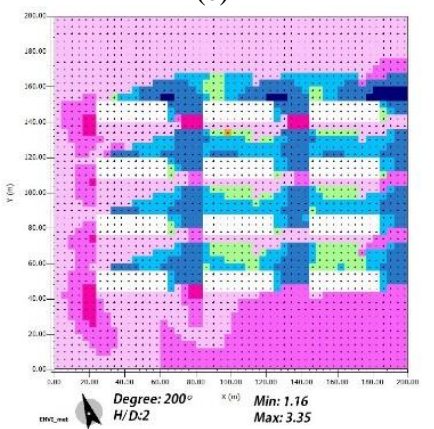

(h)

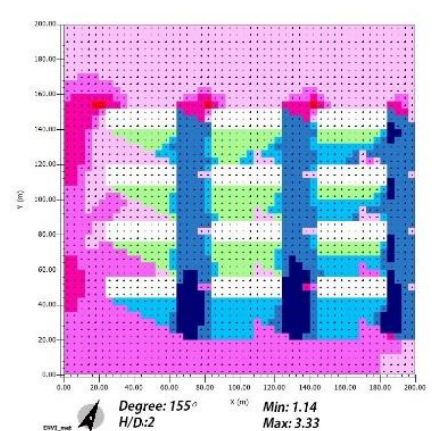

(c)

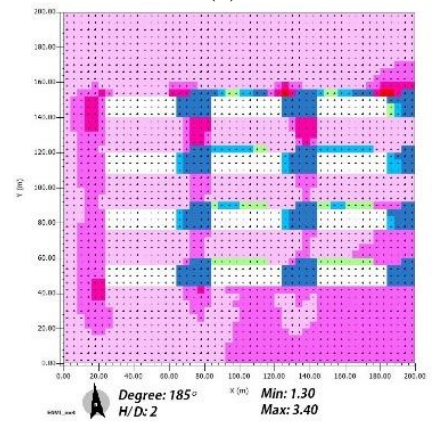

(f)

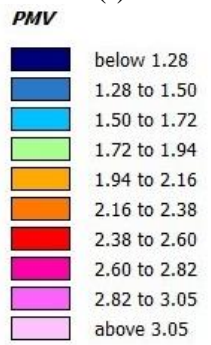

16.00.01 22.06.2020

$x / y$ out at $k=1(z=1.5000 \mathrm{~m})$

Figure 10. Display of PMV at different orientations in summer at $4 \mathrm{pm}$, (a) $135^{\circ}$, (b) $145^{\circ}$, (c) $155^{\circ}$, (d) $165^{\circ}$, (e) $175^{\circ}$, (f) $185^{\circ}$, (g) $195^{\circ}$, (h) $200^{\circ}$

Table 5. Mean of PMV in each of the receptors from 9 am to $8 \mathrm{pm}$

\begin{tabular}{|c|c|c|c|c|c|c|c|c|c|c|c|c|c|c|c|c|}
\hline \multirow{2}{*}{ Orientation } & \multicolumn{8}{|c|}{ Summer } & \multicolumn{8}{|c|}{ Winter } \\
\hline & 01 & $\mathbf{O 2}$ & $\mathbf{O 3}$ & 04 & 05 & O6 & 07 & O8 & 01 & 02 & $\mathbf{O 3}$ & 04 & 05 & O6 & 07 & O8 \\
\hline R1 & 1.63 & 1.78 & 1.84 & 1.88 & 1.61 & 1.36 & 1.16 & 1.08 & -5.22 & -5.31 & -5.29 & -5.24 & -5.16 & -5.06 & -4.95 & -4.87 \\
\hline $\mathbf{R} 2$ & 1.45 & 1.43 & 1.65 & 1.48 & 1.12 & 1.03 & 1.05 & 1.18 & -4.88 & -4.97 & -4.97 & -4.94 & -4.89 & -4.81 & -4.65 & -4.66 \\
\hline $\mathbf{R 3}$ & 1.48 & 1.70 & 1.74 & 1.71 & 1.53 & 1.41 & 1.22 & 1.10 & -5.19 & -5.27 & -5.25 & -5.21 & -5.17 & -5.07 & -4.92 & -4.87 \\
\hline R4 & 1.37 & 1.48 & 1.69 & 1.52 & 1.11 & 1.00 & 1.00 & 1.14 & -4.86 & -4.94 & -4.94 & -4.94 & -4.90 & -4.86 & -4.65 & -4.71 \\
\hline
\end{tabular}

Therefore, the comparison of the obtained numbers shows that with increasing H/D ratio, the UTCI index decreases in both seasons. In summer, this decreasing trend is the highest when it changes from a ratio of 1 to 1.5 , and the lowest when changing this ratio from 1.5 to 2. In winter, the decreasing trend of this index is the highest in changing the ratio of 0.5 to 1 , and by changing the ratio from 1.5 to 2 , as in summer, the decreasing trend is the lowest. Also, the declining trend of this index in summer is more than winter. Figures 12 and 13 display the UTCI index, extracted from the software at $4 \mathrm{pm}$ in summer and $1 \mathrm{pm}$ in winter (the hour when the PMV is the highest). In these figures, the effect of increasing the height on this index can be seen in both seasons. As a result, $H / D=2,1.5$ ratios are the best option for summer, and $H / D=0.5$ ratios are the best for winter. 


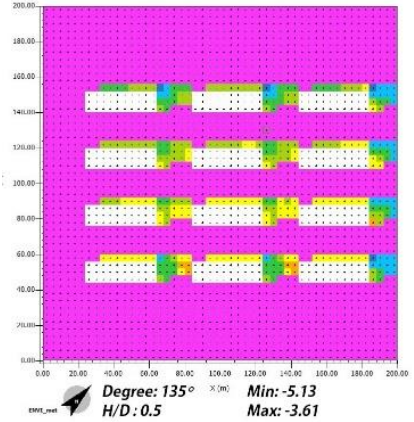

(a)

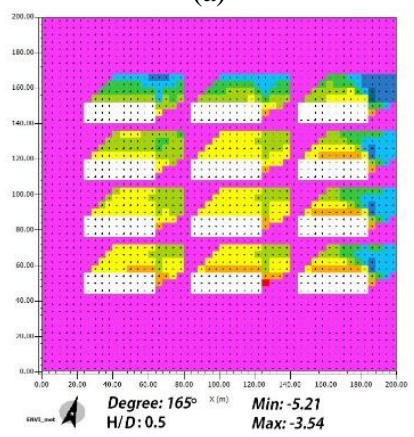

(d)

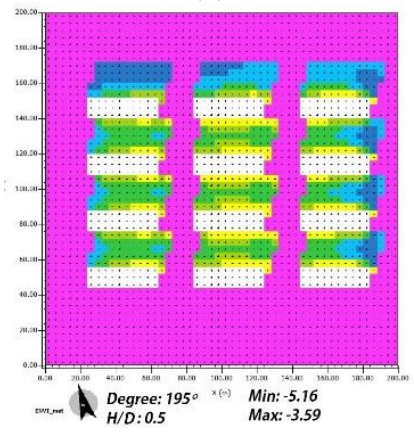

(g)

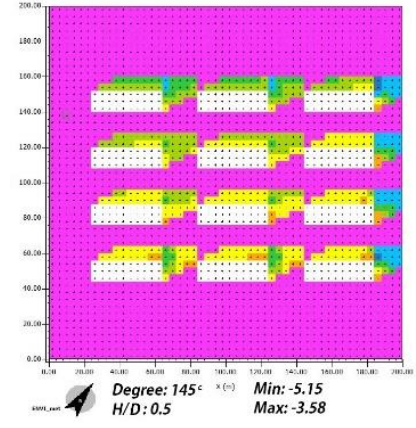

(b)

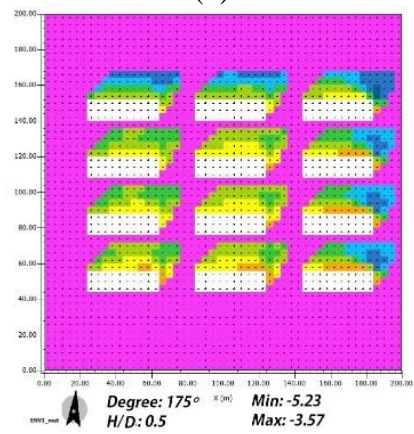

(e)

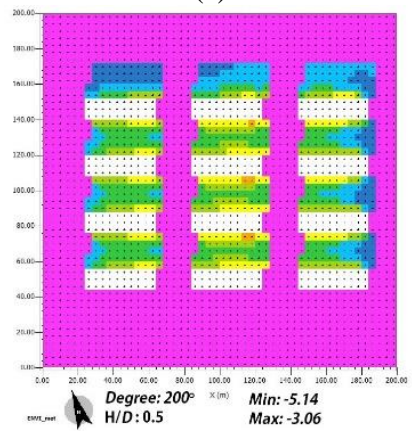

(h)

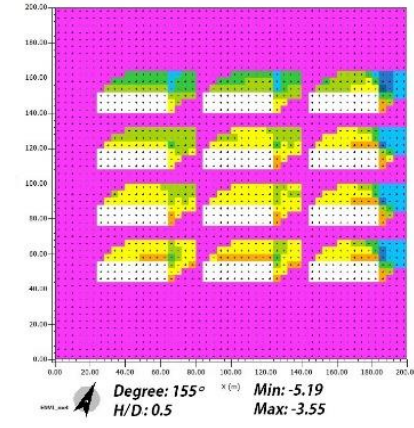

(c)

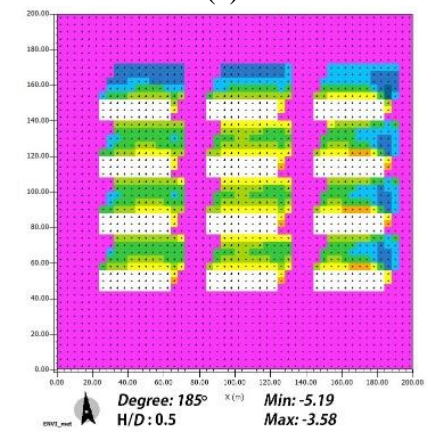

(f)

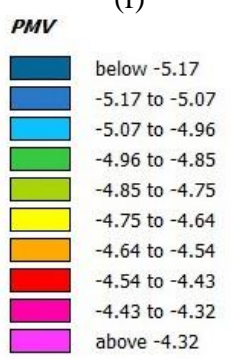

14.00.01 22.12.2020

$x / y$ Cut at $k=1(z=1.5000 \mathrm{~m})$

Figure 11. Display of PMV at different orientations in winter at $2 \mathrm{pm}$, (a) $135^{\circ}$, (b) $145^{\circ}$, (c) $155^{\circ}$, (d) $165^{\circ}$, (e) $175^{\circ}$, (f) $185^{\circ}$, (g) $195^{\circ}$, (h) $200^{\circ}$

\section{The effect of buildings orientation on UTCI}

Table 8 displays that in summer, angles of $135^{\circ}$ and $145^{\circ}$ have the lowest average of UTCI and angles of $175^{\circ}, 185^{\circ}$ have the highest average of this index at most hours of the day. The average of this index is the lowest at an angle of $135^{\circ}$ in receptors 1 and 3 and it is $26.50^{\circ} \mathrm{C}$, and $26.99^{\circ} \mathrm{C}$, respectively. In these two receptors, the maximum average is at an angle of $175^{\circ}$, which is $32.29^{\circ} \mathrm{C}$ in receptor 1 and $31.44^{\circ} \mathrm{C}$ in receptor 3 . In receptors 2 and 4 , it has the lowest value at an angle of $155^{\circ}$ and is equal to $25.28^{\circ} \mathrm{C}$ and $24.97^{\circ} \mathrm{C}$, respectively. Also, in these two receptors, the highest average is observed at an angle of $185^{\circ}$, equal to $28.33^{\circ} \mathrm{C}$ and $28.76^{\circ} \mathrm{C}$, respectively (Table 9). The difference between the maximum and minimum average of the UTCI is the highest at 9 am, $3 \mathrm{pm}$ to $5 \mathrm{pm}$, which is about $9.09^{\circ} \mathrm{C}$ at 9 am (Table 8 ). The figures obtained from the software at $4 \mathrm{pm}$, the time when the UTCI index reached its highest value, show that more favorable environmental conditions have been created at the angles of $135^{\circ}$ and $145^{\circ}$ and the PMV index is highest at the angles of $185^{\circ}$ and $175^{\circ}$ (Figure 14).

In winter, most receptors have the highest average of UTCI at an angle of $135^{\circ}$ and $145^{\circ}$. Also, the lowest average of this index in most receptors is at the angles of $195^{\circ}, 185^{\circ}$ (Table 9). Table 8 displays that in most hours of the day, the highest average of this index occurred at angles of $135^{\circ}$ and $145^{\circ}$. The difference between the maximum and minimum average of the UTCI is the highest from $1 \mathrm{pm}$ to $3 \mathrm{pm}$, which is equal to $16.50^{\circ} \mathrm{C}$ at $2 \mathrm{pm}$. Also, the figures obtained from the software at 1 $\mathrm{pm}$, the time when the UTCI index reached its highest value, show that more favorable environmental conditions have been created at the angles of $135^{\circ}$ and $145^{\circ}$. The UTCI index is lowest at the angles of $200^{\circ}$, $195^{\circ}, 185^{\circ}$ (Figure 15). 
Table 6. Mean of UTCI in four receptors from 9:00 am to 8:00 pm

\begin{tabular}{|c|c|c|c|c|c|c|c|c|c|c|c|c|c|}
\hline & \multirow[b]{2}{*}{ H/D } & \multicolumn{12}{|c|}{ Time } \\
\hline & & 09.00 & 10.00 & 11.00 & 12.00 & 13.00 & 14.00 & 15.00 & 16.00 & 17.00 & 18.00 & 19.00 & 20.00 \\
\hline \multirow{6}{*}{ Summer } & 0.5 & 31.34 & 31.84 & 33.78 & 36.34 & 37.08 & 39.13 & 40.21 & 41.25 & 38.31 & 29.96 & 21.99 & 21.04 \\
\hline & 1 & 31.14 & 31.45 & 32.72 & 34.32 & 35.09 & 37.93 & 37.90 & 37.93 & 37.08 & 28.44 & 21.98 & 21.00 \\
\hline & 1.5 & 30.16 & 30.43 & 30.75 & 29.14 & 33.05 & 34.81 & 36.02 & 36.15 & 30.58 & 25.80 & 21.57 & 20.61 \\
\hline & 2 & 30.09 & 30.38 & 30.72 & 29.10 & 33.02 & 34.79 & 36.00 & 36.14 & 30.57 & 25.79 & 21.56 & 20.60 \\
\hline & Min & 30.09 & 30.38 & 30.72 & 29.10 & 33.02 & 34.79 & 36.00 & 36.14 & 30.57 & 25.79 & 21.56 & 20.60 \\
\hline & $\begin{array}{c}\text { Max- } \\
\text { Min }\end{array}$ & 1.25 & 1.46 & 3.06 & 7.24 & 4.06 & 4.34 & 4.21 & 5.11 & 7.74 & 4.17 & 0.43 & 0.44 \\
\hline \multirow{6}{*}{ Winter } & 0.5 & -8.12 & 0.99 & 3.05 & 4.34 & 4.68 & -2.53 & -3.65 & -5.49 & -7.33 & -8.12 & -8.99 & -9.95 \\
\hline & 1 & -8.44 & -6.67 & 2.02 & 2.64 & 2.98 & -3.75 & -4.43 & -5.65 & -7.52 & -8.35 & -9.28 & -10.28 \\
\hline & 1.5 & -9.04 & -7.63 & 0.99 & 1.63 & 1.83 & -4.86 & -5.31 & -6.35 & -8.27 & -9.12 & -10.08 & -11.09 \\
\hline & 2 & -9.74 & -8.43 & 0.00 & 0.71 & 0.83 & -5.76 & -6.10 & -7.10 & -9.06 & -9.92 & -10.88 & -11.90 \\
\hline & $\operatorname{Max}$ & -8.12 & 0.99 & 3.05 & 4.34 & 4.68 & -2.53 & -3.65 & -5.49 & -7.33 & -8.12 & -8.99 & -9.95 \\
\hline & $\begin{array}{c}\text { Max- } \\
\text { Min }\end{array}$ & 1.62 & 9.42 & 3.05 & 3.62 & 3.86 & 3.22 & 2.45 & 1.62 & 1.72 & 1.80 & 1.89 & 1.96 \\
\hline
\end{tabular}

Table 7. Mean of UTCI in each of the receptors from 9:00 am to 8:00 pm

\begin{tabular}{|c|c|c|c|c|c|c|c|c|c|c|}
\hline \multirow{2}{*}{$\begin{array}{l}\text { UTCI } \\
\text { H/D }\end{array}$} & \multicolumn{5}{|c|}{ Summer } & \multicolumn{5}{|c|}{ Winter } \\
\hline & 0.5 & 1 & 1.5 & 2 & Min & 0.5 & 1 & 1.5 & 2 & $\operatorname{Max}$ \\
\hline R1 & 35.07 & 33.99 & 32.22 & 32.20 & 32.20 & -5.71 & -6.22 & -6.84 & -7.43 & -5.71 \\
\hline $\mathbf{R 2}$ & 31.92 & 30.61 & 28.19 & 28.16 & 28.16 & -1.33 & -2.70 & -3.22 & -3.83 & -1.33 \\
\hline $\mathbf{R 3}$ & 35.10 & 33.62 & 31.31 & 31.29 & 31.29 & -5.45 & -6.43 & -7.50 & -8.54 & -5.45 \\
\hline R4 & 32.00 & 30.77 & 27.97 & 27.94 & 27.94 & -1.22 & -3.56 & -4.87 & -5.98 & -1.22 \\
\hline
\end{tabular}

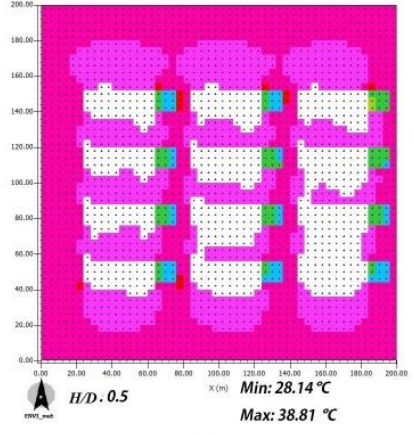

(a)

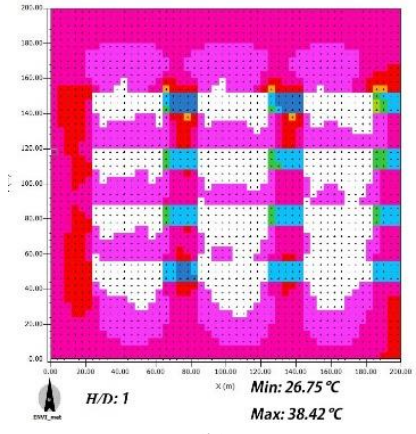

(b)

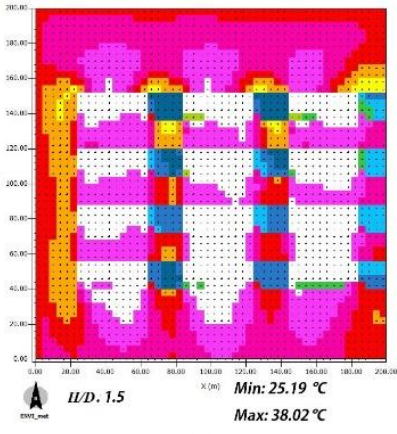

(c)

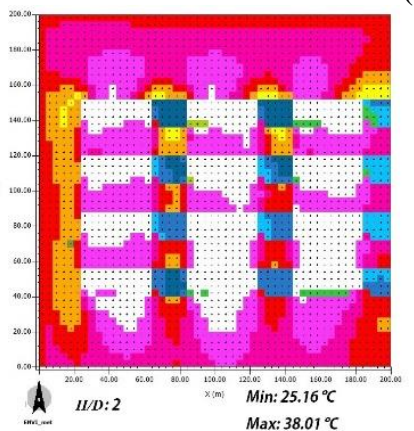

(d)

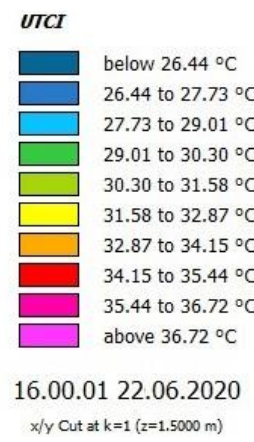

Figure 12. Display of UTCI at 4 pm in different H/D proportions in summer, (a) H/D=0.5, (b) $H / D=1$, (c) $H / D=1.5$, (d) $H / D=2$ 


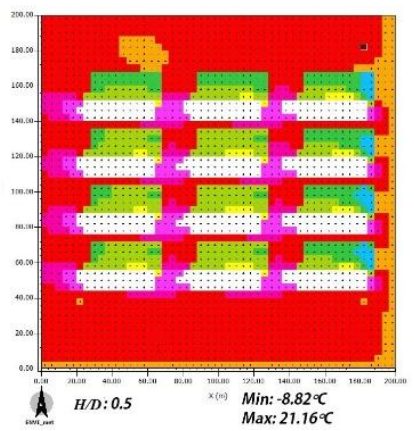

(a)

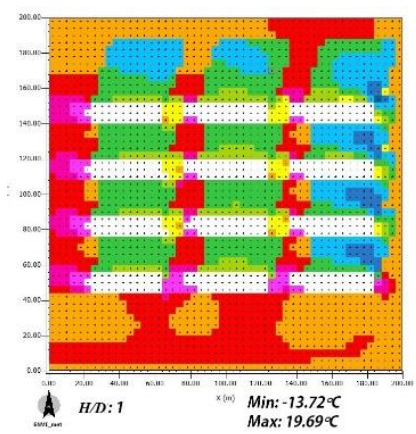

(b)

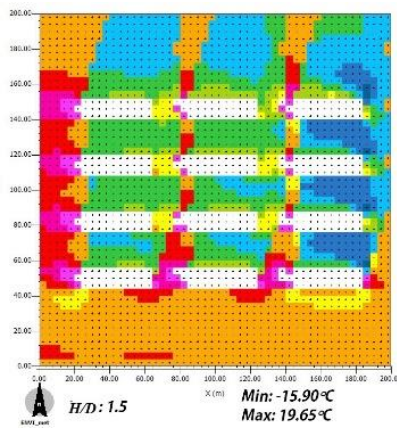

(c)

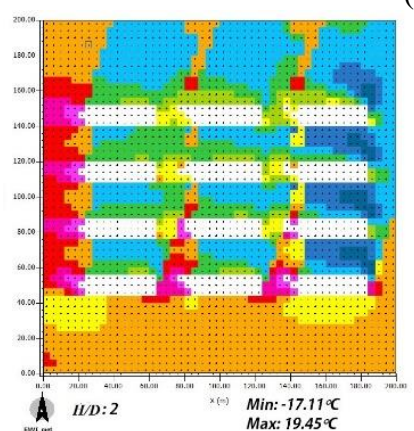

(d)

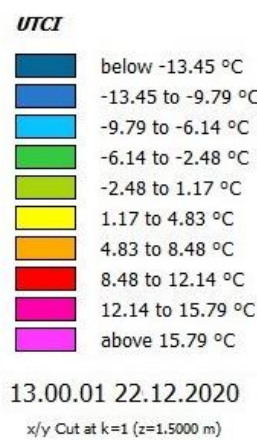

Figure 13. Display of UTCI at $1 \mathrm{pm}$ in different H/D proportions in winter, (a) $H / D=0.5$, (b) $H / D=1$, (c) $H / D=1.5$, (d) $H / D=2$

Table 8. Mean of UTCI in four receptors from 9 am to $8 \mathrm{pm}$

\begin{tabular}{|c|c|c|c|c|c|c|c|c|c|c|c|c|c|}
\hline & \multirow[b]{2}{*}{ Orientation } & \multicolumn{12}{|c|}{ Time } \\
\hline & & 09.00 & 10.00 & 11.00 & 12.00 & 13.00 & 14.00 & 15.00 & 16.00 & 17.00 & 18.00 & 19.00 & 20.00 \\
\hline \multirow{10}{*}{ Summer } & 01 & 29.97 & 30.27 & 30.60 & 31.15 & 30.50 & 28.69 & 28.95 & 30.47 & 30.63 & 29.74 & 21.33 & 20.37 \\
\hline & $\mathbf{O 2}$ & 30.10 & 30.38 & 30.49 & 31.24 & 30.56 & 29.01 & 30.92 & 32.45 & 34.37 & 29.75 & 21.40 & 20.45 \\
\hline & $\mathbf{O 3}$ & 30.10 & 30.47 & 30.65 & 29.10 & 30.48 & 34.80 & 35.93 & 36.10 & 34.22 & 25.71 & 21.50 & 20.55 \\
\hline & O4 & 30.15 & 30.59 & 29.30 & 31.05 & 32.97 & 34.59 & 35.76 & 35.96 & 28.54 & 25.78 & 21.55 & 20.58 \\
\hline & 05 & 23.72 & 25.37 & 29.15 & 30.74 & 32.48 & 34.28 & 35.37 & 30.05 & 26.34 & 24.14 & 21.26 & 20.23 \\
\hline & O6 & 21.34 & 25.20 & 29.10 & 30.72 & 32.39 & 34.18 & 30.21 & 27.97 & 26.22 & 24.09 & 21.14 & 20.11 \\
\hline & 07 & 21.06 & 24.73 & 27.55 & 30.51 & 32.09 & 33.94 & 28.16 & 27.71 & 26.19 & 24.01 & 21.04 & 20.02 \\
\hline & O8 & 22.94 & 27.76 & 27.45 & 30.25 & 32.00 & 33.74 & 27.97 & 27.46 & 25.95 & 23.81 & 20.96 & 19.98 \\
\hline & Min & 21.06 & 24.73 & 27.45 & 29.10 & 30.48 & 28.69 & 27.97 & 27.46 & 25.95 & 23.81 & 20.96 & 19.98 \\
\hline & Max-Min & 9.09 & 5.85 & 3.20 & 2.14 & 2.49 & 6.11 & 7.96 & 8.64 & 8.42 & 5.94 & 0.59 & 0.60 \\
\hline \multirow{10}{*}{ Winter } & 01 & -5.90 & -3.29 & 5.93 & 7.11 & 3.56 & 3.07 & 1.20 & -6.20 & -8.06 & -8.85 & -9.71 & -10.64 \\
\hline & $\mathbf{O 2}$ & -8.97 & -3.18 & 5.85 & 6.80 & 3.46 & 3.05 & -4.59 & -6.15 & -8.05 & -8.87 & -9.78 & -10.77 \\
\hline & $\mathbf{O 3}$ & -5.55 & -3.00 & 6.25 & 3.87 & 3.77 & 3.41 & -4.30 & -6.02 & -7.86 & -8.65 & -9.54 & -10.51 \\
\hline & O4 & -4.73 & 4.67 & 3.38 & 4.56 & 4.76 & -2.49 & -3.57 & -5.43 & -7.22 & -7.99 & -8.86 & -9.81 \\
\hline & 05 & -3.74 & 5.87 & 4.51 & 5.72 & 5.89 & -1.23 & -2.42 & -3.02 & -6.18 & -6.94 & -7.80 & -8.74 \\
\hline & O6 & 4.00 & 3.40 & 5.69 & 6.90 & 0.17 & -0.03 & 1.59 & -0.57 & -5.09 & -5.82 & -6.66 & -7.58 \\
\hline & 07 & 1.45 & 4.21 & 6.80 & 7.89 & 1.22 & 13.98 & 11.06 & 2.83 & -4.32 & -5.05 & -5.87 & -6.76 \\
\hline & O8 & 1.60 & 4.68 & 7.07 & 1.34 & 15.03 & 14.01 & 11.20 & 0.46 & -4.06 & -4.80 & -5.63 & -6.52 \\
\hline & Max & 4.00 & 5.87 & 7.07 & 7.89 & 15.03 & 14.01 & 11.20 & 2.83 & -4.06 & -4.80 & -5.63 & -6.52 \\
\hline & Max-Min & 12.97 & 9.15 & 3.69 & 6.56 & 14.86 & 16.50 & 15.79 & 9.04 & 4.00 & 4.07 & 4.15 & 4.24 \\
\hline
\end{tabular}


Table 9. Mean of UTCI in each of the receptors from 9 am to $8 \mathrm{pm}$

\begin{tabular}{|c|c|c|c|c|c|c|c|c|c|c|c|c|c|c|c|c|}
\hline \multirow[b]{2}{*}{ Orientation } & \multicolumn{8}{|c|}{ Summer } & \multicolumn{8}{|c|}{ Winter } \\
\hline & 01 & $\mathbf{O 2}$ & $\mathbf{O 3}$ & 04 & 05 & O6 & 07 & 08 & 01 & $\mathbf{O 2}$ & $\mathbf{O 3}$ & 04 & 05 & 06 & O7 & 08 \\
\hline R1 & 29.26 & 30.43 & 31.49 & 32.29 & 30.67 & 28.87 & 27.39 & 26.50 & -5.44 & -6.55 & -6.15 & -5.30 & -3.66 & -1.27 & 1.50 & 4.36 \\
\hline $\mathrm{R} 2$ & 27.86 & 27.65 & 28.33 & 27.40 & 25.37 & 25.28 & 25.85 & 26.90 & -0.88 & -1.96 & -1.74 & -0.98 & 0.11 & 1.44 & 3.67 & 3.67 \\
\hline R3 & 29.32 & 30.82 & 31.29 & 31.44 & 29.81 & 28.44 & 27.07 & 26.99 & -3.54 & -3.53 & -3.26 & -3.67 & -2.51 & -2.37 & 0.48 & 2.50 \\
\hline $\mathrm{R} 4$ & 27.78 & 28.15 & 28.76 & 27.81 & 25.19 & 24.97 & 25.36 & 26.36 & -0.73 & -1.69 & -1.55 & -0.95 & 0.04 & 0.87 & 3.50 & 3.50 \\
\hline
\end{tabular}

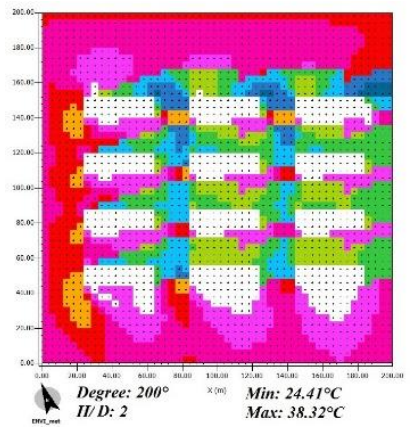

(a)

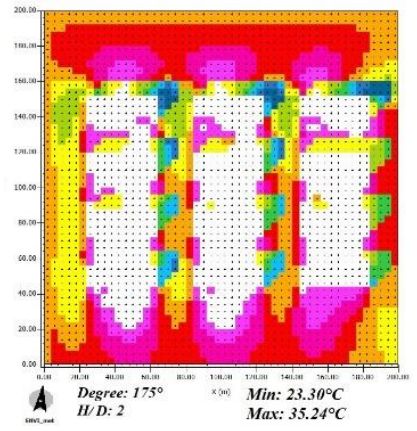

(d)

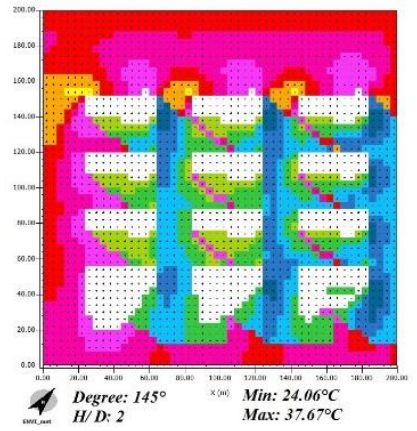

(g)

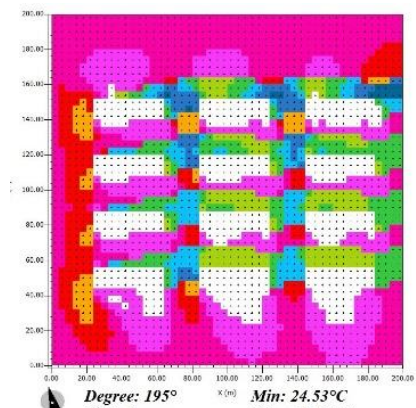

(b)

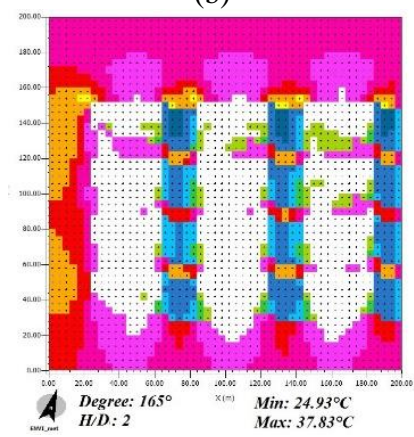

(e)

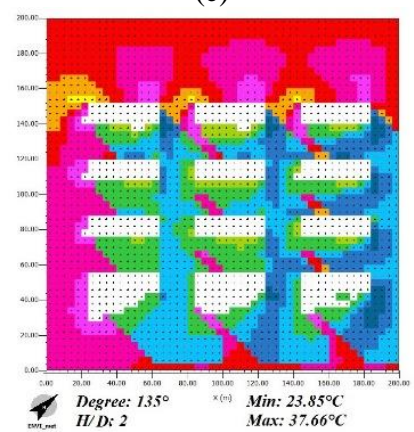

(h)

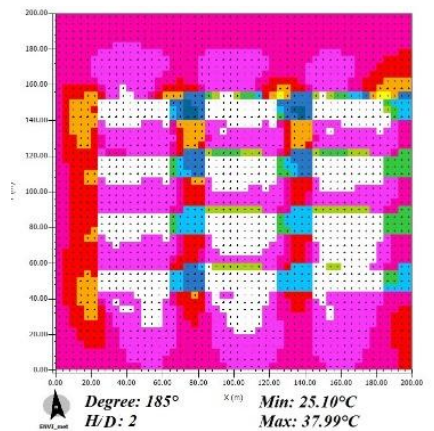

(c)

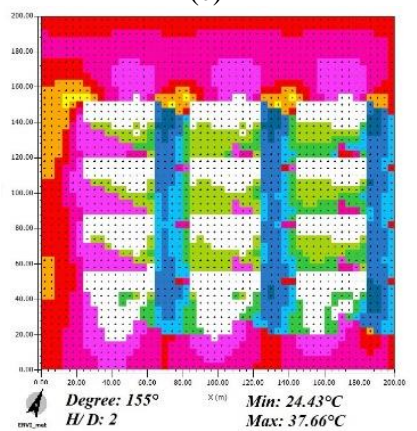

(f)

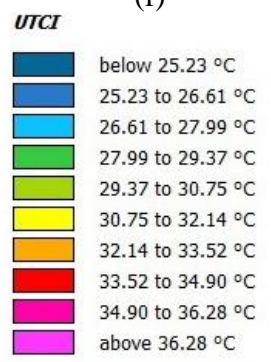

16.00.01 22.06.2020

$x / y$ Cut at $k=1(z=1.5000 \mathrm{~m})$

Figure 14. Display of UTCI at different orientations in summer at $4 \mathrm{pm}$, (a) $200^{\circ}$, (b) $195^{\circ}$, (c) $185^{\circ}$, (d) $175^{\circ}$, (e) $165^{\circ}$, (f) $155^{\circ}$, (g) $145^{\circ}$, (h) $135^{\circ}$

\section{DISCUSSION}

This study investigated the thermal comfort conditions in the outdoor space around buildings with a linear pattern in cold semi-arid climates considering the elderly. The results show that in summer, with increasing the H/D ratio, PMV and UTCI index decreases. As these factors decrease, the outdoor environmental conditions improve. In this season, with the increase of the H/D ratio in all hours and receptors, these two factors have a downward trend. In winter, with an increasing H/D ratio, the average of PMV and UTCI decreases, and this downward trend has occurred in all four receptors. As a result, it can be concluded that, unlike summer, by reducing the H/D ratio 
due to receive more sunlight and increasing the temperature of the elements in the site and buildings, the ratio of $\mathrm{H} / \mathrm{D}=0.5$ is the most appropriate one. The results of research on the orientation of the buildings display that in summer, the average of PMV and UTCI is lowest at the angles of $135^{\circ}, 145^{\circ}$ and they are highest at the angles of $175^{\circ}$ and $185^{\circ}$. Therefore, considering these two factors in this season, angles of $135^{\circ}, 145^{\circ}$ are the most suitable, and angles of $175^{\circ}, 185^{\circ}$ are the most inappropriate. Angles of the $200^{\circ}, 195^{\circ}, 155^{\circ}$, and $165^{\circ}$ have moderate conditions. In winter, the average of PMV and UTCI is lowest at the angles of $135^{\circ}, 145^{\circ}$ and they are highest at the angles of $185^{\circ}$ and $195^{\circ}$. Therefore, considering these two factors in this season, angles of $135^{\circ}, 145^{\circ}$ are the most suitable, and angles of $185^{\circ}, 195^{\circ}$ are the most inappropriate. Angles of the $200^{\circ}, 175^{\circ}, 165^{\circ}$, and $155^{\circ}$ have moderate conditions.

Martinelli et al. [7] recommend higher H/D for summer in Italy with warm climates and lower H/D in parts of Italy with cold climates. Achour-Younsi and Kharrat [13] have investigated this ratio at subtropical Mediterranean climates. They have concluded that as H/D increases, the thermal comfort improves in summer. They have introduced north-south orientation as the best one. Johansson et al. [20] have investigated this factor in Sao Paulo, with a warm and humid climate in summer. They have concluded that in most hours of the day, high-rise buildings are better than others because they give more shade. Also, they have recommended northwestsoutheast and southwest-northeast orientations. Also, AliToudert and Mayer [21] have recommended northwestsoutheast and southwest-northeast orientations in the hot and dry climate of Algeria. Targhi and Van Dessel [22] have found the northwest orientation better than others in Worcester. So, regarding the H/D ratio, this study agrees with other similar studies that have been done in different climates. About the orientation of the buildings, the four main directions, East-West (EW), North-South (NS),

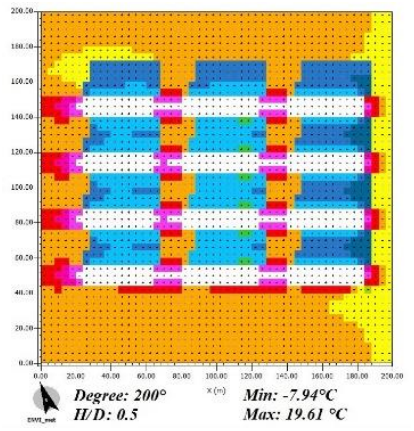

(a)

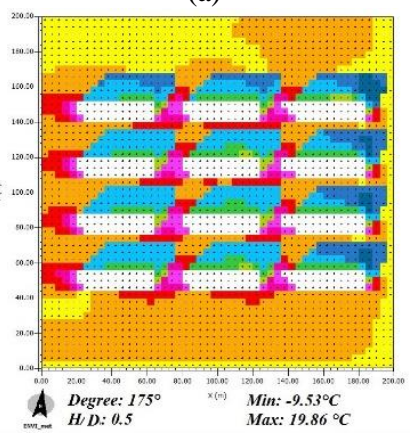

(d)

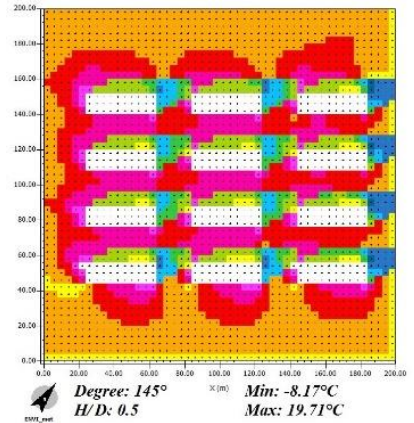

(g)

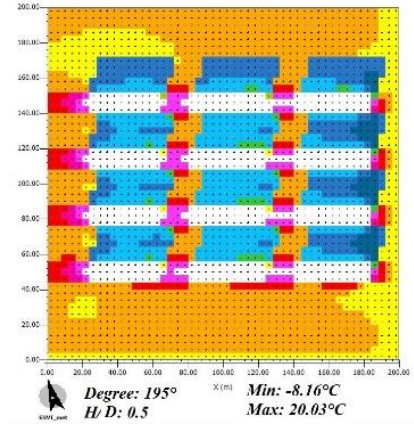

(b)

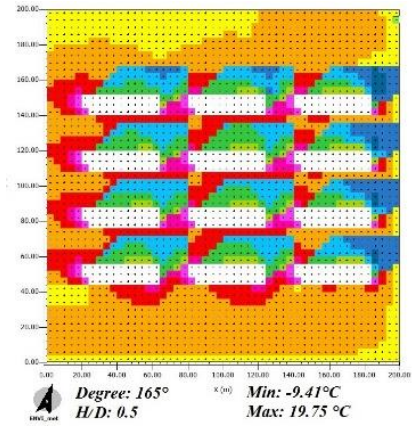

(e)

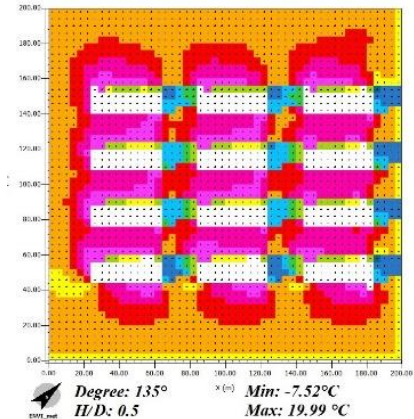

(h)

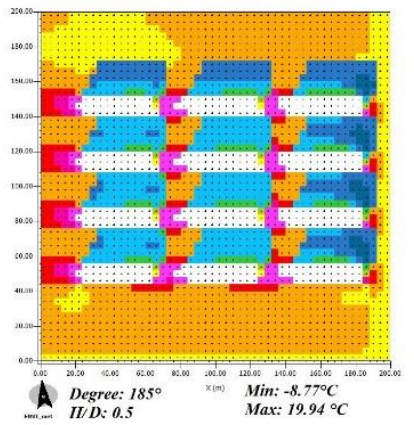

(c)

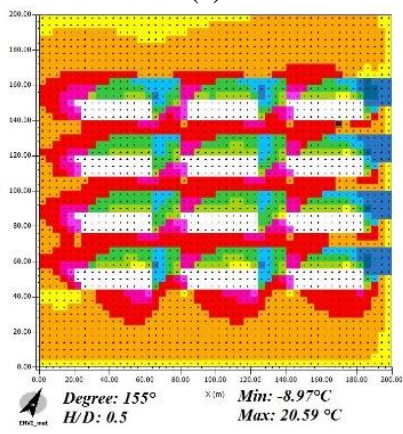

(f)

UTCI

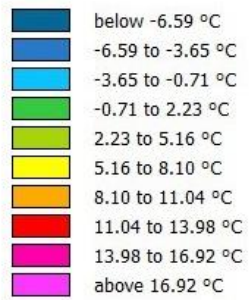

$13 . .00 .01 \quad 22.12 .2020$

$\mathrm{x} / \mathrm{y}$ Cut at $\mathrm{k}=1(\mathrm{z}=1.5000 \mathrm{~m})$

Figure 15. Display of UTCI at different orientations in winter at $1 \mathrm{pm}$, (a) $200^{\circ}$, (b) $195^{\circ}$, (c) $185^{\circ}$, (d) $175^{\circ}$, (e) $165^{\circ}$, (f) $155^{\circ}$, (g) $145^{\circ}$, (h) $135^{\circ}$ 
Northeast-Southwest (NE-SW), Northwest-Southeast (NW-SE) have examined in other researches, in this article, the eight different angles have been investigated. Therefore, it has some differences with other articles reviewed in this field.

\section{CONCLUSION}

This research searches suitable outdoor thermal comfort in residential blocks considering the elderly, assuming that the factors of the H/D and orientation of the blocks can affect environmental conditions. Also, PMV and UTCI are the most important indexes in the study of thermal comfort. By examining the number of changes that occur in these indexes in changing the H/D ratio, it can be concluded that in summer, with increasing H/D ratio, in most hours of the day, they have a downward trend. The declining of the indexes in changing the ratios is not the same and reaches the maximum value by changing the ratio from 1 to 1.5 . Also, in winter, they have a decreasing trend with increasing H/D. Increasing the $\mathrm{H} / \mathrm{D}$ ratio in summer has a more significant impact on outdoor environmental conditions than winter. Therefore, considering both seasons, the ratio of $\mathrm{H} / \mathrm{D}=1.5$ can be regarded as the most appropriate one. Also, the $\mathrm{H} / \mathrm{D}=0.5$ can be suitable provided that other factors are taken into account to improve the thermal comfort in summer. These factors can be such as green space, materials used with lower albedo and lighter colors. Also, considering both seasons, the angles of $135^{\circ}$ and $145^{\circ}$ are the most appropriate among others. It is recommended that future research investigate outdoor thermal comfort for different age groups such as children or different genders such as women in other types of buildings.

\section{REFERENCES}

1. Al-Khazzar, A. 2017. "The Required Land Area for Installing a Photovoltaic Power Plant." Iranian (Iranica) Journal of Energy \& Environment, $8(1), \quad$ pp.11-17. Doi:10.5829/IDOSI.IJEE.2017.08.01.03

2. Tayari, M., and Burman, E. 2018. "Electrical Energy Auditing by Analyzing End-Use Energy Consumption: A Case Study of an Office Building in Tehran." Iranian (Iranica) Journal of Energy \& Environment, 9(33), pp.153-162. Doi: 10.5829/IJEE.2018.09.03.01

3. Mohammad Alinezhad, F. 2019. "Passive Cooling in Shavadoon of Traditional Buildings of Dezful City: Cooling Through Renewable Energy Sources." Iranian (Iranica) Journal of Energy \& Environment, 10(2), pp.115-120. Doi: 10.5829/IJEE.2019.10.02.08

4. Mirzabeigi, S., and Razkenari, M. 2022. "Design optimization of urban typologies: A framework for evaluating building energy performance and outdoor thermal comfort." Sustainable Cities and Society, 76, 103515. Doi: 10.1016/J.SCS.2021.103515

5. Apreda, C., Reder, A., and Mercogliano, P. 2020. "Urban morphology parameterization for assessing the effects of housing blocks layouts on air temperature in the Euro-Mediterranean context." Energy and Buildings, 223, 110171. Doi: 10.1016/J.ENBUILD.2020.110171

6. Andreou, E. 2013. "Thermal comfort in outdoor spaces and urban canyon microclimate." Renewable Energy, 55, pp.182-188. Doi: 10.1016/J.RENENE.2012.12.040

7. Martinelli, L., and Matzarakis, A. 2017. "Influence of height/width proportions on the thermal comfort of courtyard typology for Italian climate zones." Sustainable Cities and Society, 29, pp.97-106. Doi: 10.1016/J.SCS.2016.12.004

8. Galal, O. M., Sailor, D. J., and Mahmoud, H. 2020. "The impact of urban form on outdoor thermal comfort in hot arid environments during daylight hours, case study: New Aswan." Building and Environment, 184, 107222. Doi: 10.1016/J.BUILDENV.2020.107222

9. Yao, F., Fang, H., Han, J., and Zhang, Y. 2022. "Study on the outdoor thermal comfort evaluation of the elderly in the Tibetan plateau." Sustainable Cities and Society, 77, 103582. Doi: 10.1016/J.SCS.2021.103582

10. Jiao, Y., Yu, H., Wang, T., An, Y., and Yu, Y. 2017. "Thermal comfort and adaptation of the elderly in free-running environments in Shanghai, China." Building and Environment, 118, pp.259-272. Doi: 10.1016/J.BUILDENV.2017.03.038

11. Forcada, N., and Tejedor, B. 2020. "Evaluation of thermal comfort in elderly care centres (ECC)." Windsor 2020 Resilient Comfort: proceedings conference scheduled 16th-19th April 2020, pp.200215. $\quad$ Retrieved from https://upcommons.upc.edu/handle/2117/327124

12. Fanger, P. O. 1970. Thermal comfort. Analysis and applications in environmental engineering. Copenhagen: Danish Technical Press. Retrieved from https://www.cabdirect.org/cabdirect/abstract/19722700268

13. Achour-Younsi, S., and Kharrat, F. 2016. "Outdoor Thermal Comfort: Impact of the Geometry of an Urban Street Canyon in a Mediterranean Subtropical Climate - Case Study Tunis, Tunisia." Procedia - Social and Behavioral Sciences, 216, pp.689-700. Doi: 10.1016/J.SBSPRO.2015.12.062

14. Abdi, B., Hami, A., and Zarehaghi, D. 2020. "Impact of smallscale tree planting patterns on outdoor cooling and thermal comfort." Sustainable Cities and Society, 56, 102085. Doi: 10.1016/J.SCS.2020.102085

15. Nasrollahi, N., Hatami, M., Khastar, S. R., and Taleghani, M. 2017. "Numerical evaluation of thermal comfort in traditional courtyards to develop new microclimate design in a hot and dry climate." Sustainable Cities and Society, 35, pp.449-467. Doi: 10.1016/J.SCS.2017.08.017

16. Taleghani, M., and Berardi, U. 2018. "The effect of pavement characteristics on pedestrians' thermal comfort in Toronto." Urban Climate, 24, pp.449-459. Doi: 10.1016/J.UCLIM.2017.05.007

17. Middel, A., Häb, K., Brazel, A. J., Martin, C. A., and Guhathakurta, S. 2014. "Impact of urban form and design on midafternoon microclimate in Phoenix Local Climate Zones." Landscape and Urban Planning, 122, pp.16-28. Doi: 10.1016/J.LANDURBPLAN.2013.11.004

18. Matzarakis, A., Rutz, F., and Mayer, H. 2007. "Modelling radiation fluxes in simple and complex environments Application of the RayMan model." International Journal of Biometeorology, 51(4), pp.323-334. Doi: 10.1007/S00484-0060061-8/FIGURES/11

19. Ghiabakloo, Z. 2003. "Shadow movement pattern and site design - Google Scholar." Tehran: Art University, 15, pp.58-68. Retrieved from https://scholar.google.com/scholar?hl=en\&as_sdt=0\%2C5\&q=Sh 
adow+movement+pattern+and+site+design\&btnG=

20. Johansson, E., Spangenberg, J., Gouvêa, M. L., and Freitas, E. D. 2013. "Scale-integrated atmospheric simulations to assess thermal comfort in different urban tissues in the warm humid summer of São Paulo, Brazil." Urban Climate, 6, pp.24-43. Doi: 10.1016/J.UCLIM.2013.08.003

21. Ali-Toudert, F., and Mayer, H. 2006. "Numerical study on the effects of aspect ratio and orientation of an urban street canyon on outdoor thermal comfort in hot and dry climate." Building and Environment, 41(2), pp.94-108. Doi: 10.1016/J.BUILDENV.2005.01.013

22. Targhi, M. Z., and Van Dessel, S. 2015. "Potential Contribution of Urban Developments to Outdoor Thermal Comfort Conditions: The Influence of Urban Geometry and Form in Worcester, Massachusetts, USA.” Procedia Engineering, 118, pp.11531161. Doi: 10.1016/J.PROENG.2015.08.457

\section{COPYRIGHTS}

C2021 The author(s). This is an open access article distributed under the terms of the Creative Commons Attribution (CC BY 4.0), which permits unrestricted use, distribution, and reproduction in any medium, as long as the original authors and source are cited. No permission is required from the authors or the publishers.

يكى از عوامل حياتى براى حضور بيشتر افراد در فضاى باز، ايجاد شرايط آسايشى است. اين موضوع با توجه به شرايط جسمى متفاوت براى سالمندان قابل توجه

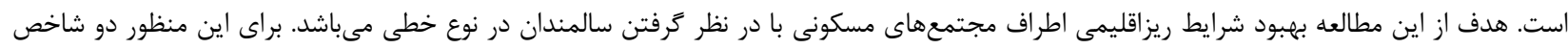

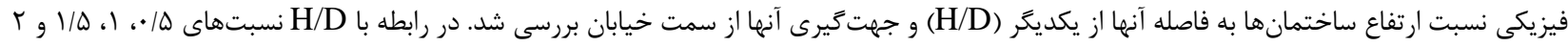

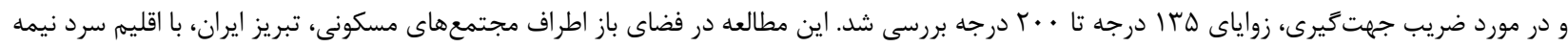

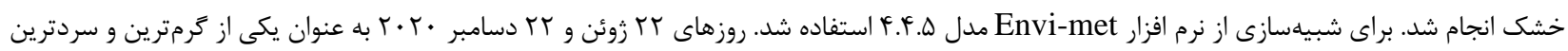

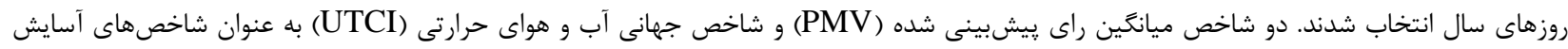

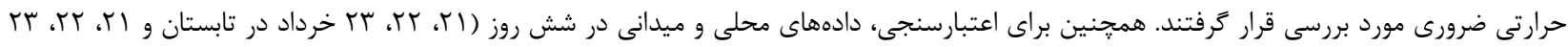

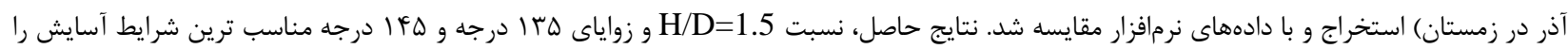

